\title{
The hepatitis C virus (HCV) protein, p7, suppresses inflammatory responses to tumor necrosis factor (TNF)- $\alpha$ via signal transducer and activator of transcription (STAT)3 and extracellular signal-regulated kinase (ERK)-mediated induction of suppressor of cytokine signaling (SOCS)3
}

\author{
Orla Convery, ${ }^{*, 1}$ Siobhan Gargan, ${ }^{*, 1}$ Michelle Kickham, ${ }^{+}$Martina Schroder, ${ }^{+}$Cliona ${ }^{\prime}$ Farrelly, ${ }^{,, * 2}$ \\ and Nigel J. Stevenson ${ }^{*, 2,3}$ \\ *School of Biochemistry and Immunology, Trinity Biomedical Sciences Institute and "School of Medicine, Trinity College Dublin, Dublin, \\ Ireland; and ${ }^{\dagger}$ Biology Department, Maynooth University, Maynooth, Ireland
}

\begin{abstract}
Viruses use a spectrum of immune evasion strategies that enable infection and replication. The acute phase of hepatitis C virus (HCV) infection is characterized by nonspecific and often mild clinical symptoms, suggesting an immunosuppressive mechanism that, unless symptomatic liver disease presents, allows the virus to remain largely undetected. We previously reported that $\mathrm{HCV}$ induced the regulatory protein suppressor of cytokine signaling (SOCS)3, which inhibited TNF- $\alpha$-mediated inflammatory responses. However, the mechanism by which HCV up-regulates SOCS3 remains unknown. Here we show that the HCV protein, p7, enhances both SOCS3 mRNA and protein expression. A p7 inhibitor reduced SOCS3 induction, indicating that p7's ion channel activity was required for optimal up-regulation of SOCS3. Short hairpin RNA and chemical inhibition revealed that both the Janus kinase-signal transducer and activator of transcription (JAK-STAT) and MAPK pathways were required for p7-mediated induction of SOCS3. HCV-p7 expression suppressed TNF- $\alpha$-mediated IкB- $\alpha$ degradation and subsequent NF-кB promoter activity, revealing a new and functional, anti-inflammatory effect of p7. Together, these findings identify a molecular mechanism by which HCV-p7 induces SOCS3 through STAT3 and ERK activation and demonstrate that $\mathrm{p} 7$ suppresses proinflammatory responses to TNF- $\alpha$, possibly explaining the lack of inflammatory symptoms observed during early HCV infection.-Convery, O., Gargan, S., Kickham, M., Schroder, M., O'Farrelly, C., Stevenson, N. J. The hepatitis C virus (HCV) protein, p7, suppresses inflammatory responses to tumor necrosis factor (TNF)- $\alpha$ via signal transducer and activator of transcription (STAT)3 and extracellular signal-regulated kinase (ERK)-mediated induction of suppressor of cytokine signaling (SOCS)3. FASEB J. 33, 8732-8744 (2019). www.fasebj.org
\end{abstract}

KEY WORDS: inflammation - viral immune evasion · intracellular signaling pathways · immune regulation · JAK-STAT signalling pathway

Hepatitis $\mathrm{C}$ virus (HCV) infection can lead to cirrhosis, liver failure, and hepatocellular carcinoma (1,2); however, infected individuals often remain outwardly healthy for many years $(3,4)$. HCV is detected by pathogen recognition receptors of the innate immune system, which stimulate the secretion of type I interferons (IFNs) (5-7).

\footnotetext{
ABBREVIATIONS: AP-1, activating protein 1; CIS, cytokine-inducible Src homology 2 domain-containing protein; ER, endoplasmic reticulum; EV, empty vector; GAS, $\gamma$-activated site; GT1a, genotype 1a; GT2a, genotype 2a; HA, human influenza hemagglutinin; HCV, hepatitis C virus; HEK, human embryonic kidney; ISG, IFN-stimulated gene; ISRE, IFN-stimulated response element; JAK, Janus kinase; Jc1 $\Delta$ p7, Jc1 with a partial p7 deletion; NS, nonstructural protein; PMA, phorbol myristate acetate; qRT-PCR, quantitative RT-PCR; shRNA, short hairpin RNA; RPS15, 40S ribosomal protein S15; SOCS, suppressor of cytokine signaling; STAT, signal transducer and activator of transcription; TRAF, TNF receptor-associated factor

1 These authors contributed equally to this work.

2 These authors contributed equally to this work.

${ }^{3}$ Correspondence: Intracellular Immunology Group, School of Biochemistry and Immunology, Trinity Biomedical Sciences Institute, Trinity College Dublin, 152-160 Pearse St., Dublin 2, Ireland. E-mail: n.stevenson@tcd.ie
} 
Binding of IFN- $\alpha$ activates the IFN- $\alpha$ receptor complex (IFN- $\alpha$ receptors 1 and 2), resulting in the subsequent phosphorylation and activation of the receptor-associated protein tyrosine kinases, Janus kinase (JAK) 1 and tyrosine kinase 2, which phosphorylate receptor tyrosine residues in the cytoplasmic region. This enables signal transducer and activator of transcription (STAT) proteins to bind the receptor via their Src homology 2 domains (8). Phosphorylated STAT proteins translocate to the nucleus and bind to $\gamma$-activated sites (GASs) and IFN-stimulated response elements (ISREs), inducing transcription of IFN-stimulated genes (ISGs), which are essential for viral clearance (9-11). Specifically, activated STAT3 dimers bind GAS promoter sequences $(12,13)$, whereas activated STAT1, STAT2, and IFN regulatory factor 9 trimers recognize the ISRE DNA elements (13), resulting in distinct antiviral and proinflammatory gene induction.

Interestingly, even though innate immunity provides an immediate and effective response, the acute phase of $\mathrm{HCV}$ infection is often asymptomatic (14), for reasons that remain poorly understood. However, this lack of clinical symptoms indicates that HCV has evolved antiinflammatory mechanisms to effectively counteract immune responses. Indeed, cleavage of adaptor proteins, mitochondrial antiviral signaling protein (MAVS), and Toll/interleukin-1 receptor (TIR) domain-containing adaptor protein-inducing IFN- $\beta$ (TRIF) disrupt retinoic acid inducible gene-I (RIG-I) and Toll-like receptor (TLR)3 signaling, respectively, revealing viral processes that block HCV detection and subsequent type IIFN induction (15-17). We have previously shown that HCV also degrades essential components of the type I IFN JAK-STAT pathway via the ubiquitin-proteasome system, thereby blocking induction of functional antiviral ISGs (18). We also found that HCV induces expression of the intracellular inhibitor, suppressor of cytokine signaling (SOCS)3, a negative regulator of both the JAK-STAT and NF$\kappa B$ pathways (19). Therefore, we propose that HCVmediated SOCS3 induction, in turn, suppresses TNF- $\alpha$ 's proinflammatory signaling (19), perhaps providing some explanation for $\mathrm{HCV}^{\prime}$ 's clinical silence during the period of acute infection.

The SOCS family of proteins consists of 8 members [cytokine-inducible Src homology 2 domain-containing protein (CIS) and SOCS1-7] that regulate signal transduction (20). Although SOCS classically inhibit the JAKSTAT pathway through direct interaction with JAKs, or the receptor, or both $(21,22)$, they also suppress other pathways, including the NF- $\kappa$ B signaling cascade. In fact, SOCS3 is thought to suppress NF- $\mathrm{BB}$ signaling via association with TNF receptor-associated factor (TRAF) family member-associated NF- $\mathrm{kB}$ activator (TANK)-binding kinase 1 (TBK1) TRAF2, and TRAF6 (19, 23-26). Because SOCS proteins control many inflammatory responses, it is no surprise that viruses have evolved to harness this suppressive power, essentially controlling the host's innate antiviral activity (27). Bode et al. (28) previously reported that HCV's core protein up-regulated SOCS3, which is thought to block IFN- $\alpha$-induced STAT1 phosphorylation. Additionally, Hsieh et al. (29) found that HCV
E2 expression led to a dose-dependent increase in the SOCS3 gene and protein of Huh7 cells. They also showed that E2 expression resulted in insulin receptor substrate-1 degradation, which was restored following MG132 treatment. The authors suggested that E2-mediated SOCS3 may target insulin receptor substrate-1 for degradation, thereby regulating insulin signaling. Although elevated SOCS3 has been observed in the liver of HCV-infected humans and chimpanzees (30), its high expression may explain the lack of response to pegylated IFN- $\alpha$ and ribavirin treatment $(31,32)$. The correlation between chronic $\mathrm{HCV}$ infection and increased SOCS3 indicates an important role for this protein in HCV's immune evasion and modulation strategy. However, whether other HCV proteins (apart from HCV core and E2) induce SOCS3 and the exact mechanism by which HCV enhances SOCS3 expression have not been explored.

Diverse stimuli, including cytokines, grow th factors, and bacterial and viral pathogen-associated molecular patterns, stimulate SOCS3 induction (33). Transcriptional activation of SOCS genes is classically mediated by the STAT transcription factors (34). STAT3 has been found to regulate SOCS3 induction (35-37), with both STAT1 and STAT5 also playing a role $(38,39)$. In addition to the JAK-STAT cascade, there is a growing body of evidence implicating other signaling pathways in the induction of SOCS3, such as that of MAPK (40). The conventional mammalian MAPKs include ERK, JNK and p38 (41). MAPK signaling can be activated by TLR or receptor tyrosine kinase engagement $(42,43)$, leading to activation of transcription factors, such as activating protein 1 (AP-1) and ETS-like protein-1 (ELK1) (44-49). All 3 MAPKs (ERK, JNK, and p38) have been shown to regulate SOCS3 expression (50-55). Although induction through these alternative pathways was initially a surprise, this insight into SOCS3's transcriptional regulation gives us a distinct advantage when explaining the mechanism by which HCV stimulates its induction.

HCV's ion channel, p7, is vital to producing infectious viral particles during viral egress (56). Although immune evasion mechanisms of several HCV proteins have been described, p7's effect on the immune response has gone largely unstudied, with p7 having only been shown to inhibit the induction of the ISG, interferon- $\alpha$ inducible protein (IFI)6-16 (57). In this study, we show that $\mathrm{p7}$ enhances SOCS3 mRNA and protein expression in hepatocytes. Using a p7 inhibitor, we discovered that p7 ion channel activity was required for this SOCS3 induction. We found that $\mathrm{p} 7$ expression led to enhanced phosphorylated STAT3, whereas short hairpin RNA (shRNA) knockdown of STAT3 prevented p7-mediated induction of SOCS3. p7 also stimulated activity of the well-known STAT3-driven promoter, GAS, revealing a downstream transcriptional effect of this viral protein. In addition, ERK phosphorylation was enhanced by $\mathrm{p} 7$, whereas chemical inhibition of upstream MEK suppressed p7-mediated induction of SOCS3. Furthermore, activation of TNF- $\alpha-$ mediated NF-кB signaling was reduced in the presence of p7, indicating a functional inhibitory effect of p7 upon inflammation. Together, these findings reveal a novel 
mechanism by which $\mathrm{p} 7$ induces SOCS3 and modulates proinflammatory signaling.

\section{MATERIALS AND METHODS}

\section{Cell culture}

Huh7, Huh7.5, and human embryonic kidney (HEK)293T cells were grown in MEM, supplemented with $10 \%$ fetal calf serum, $100 \mathrm{U} / \mathrm{ml}$ penicillin, and $100 \mu \mathrm{g} / \mathrm{ml}$ streptomycin; and cultured at $37^{\circ} \mathrm{C}$ in $5 \% \mathrm{CO}_{2}$. Cells were treated with $1000 \mathrm{IU} / \mathrm{ml}$ human IFN- $\alpha 2 \mathrm{~A}$ (Roche, Basel, Switzerland), $10 \mathrm{ng} / \mathrm{ml}$ human TNF- $\alpha$ (PeproTech, Rocky Hill, NJ, USA), $50 \mathrm{ng} / \mathrm{ml}$ lipopolysaccharide (LPS), or $50 \mathrm{ng} / \mathrm{ml}$ phorbol myristate acetate (PMA). During experiments using $\mathrm{N}$-(n-Nonyl)deoxynojirimycin (NNDNJ), cells were transfected with $1 \mu \mathrm{g}$ of HCV-p7-human influenza hemagglutinin (HA) or empty vector (EV) control for $16 \mathrm{~h}$, prior to $8 \mathrm{~h}$ treatment with 20 or $100 \mu \mathrm{M}$ of NNDNJ.

\section{Constructs}

p7 genotype 2a (GT2a) was amplified from pWPI_sp_p7_BLR (a kind gift from Ralf Bartenschlager, University of Heidelberg, Heidelberg, Germany) using the primers 5'-ATGGAGGCCCGAATTGCACTAGAGAAGCTGGTCATC-3' (forward) and 5'AGAGATCTCGGTCGATCAAGCATAAGCCTGTTGGGG-3' (reverse) and Velocity DNA polymerase (Bioline, London, United Kingdom). The product was inserted into EcoRI- and SalI(New England Biolabs, Ipswich, MA, USA) digested pCMV vector, in frame with the $\mathrm{N}$-terminal HA epitope tag by In-Fusion Cloning (Clontech Laboratories, Mountain View, CA, USA). p7 genotype 1a (GT1a) was amplified from pCMV-p7-HA using the primers 5'-ATGGAGGCCCGAATTGATGGCTTTGGAGAACCTCG-3' (forward) and 5'-AGAGATCTCGGTCGACTATGCGTATGCCCGCTG-3' (reverse) and Velocity DNA polymerase (Bioline). The product was inserted into EcoRI- and Sall- (New England Biolabs) digested pCMV vector out of frame with the $\mathrm{N}$-terminal HA epitope tag by In-Fusion Cloning (Clontech Laboratories).

\section{Transfection}

Huh7 cells were transfected with 1 or $4 \mu \mathrm{g}$ of HCV-p7-HA (HCV GT1a), HCV-p7 GT2a, or the corresponding EV controls for $24 \mathrm{~h}$ using Lipofectamine 2000 (Thermo Fisher Scientific, Waltham, MA, USA), according to the manufacturer's instructions.
HEK293T cells were transfected in 6-well plates with $1 \mu \mathrm{g}$ of shRNA STAT3 and scrambled control (InvivoGen, San Diego, CA, USA) or with 1 or $4 \mu \mathrm{g}$ of HCV-p7 GT1a or HCV-p7 GT2aHA, using Lipofectamine 2000 for $24 \mathrm{~h}$.

\section{HCV infection}

Huh7.5 cells were transfected with $1 \mu \mathrm{g}$ of Jc1, Jc1 with a partial p7 deletion (Jc1 $\Delta$ p7, a mutant lacking residues 1-32) (58) (kind gifts from Ralf Bartenschlager, Heidelberg University), or an EV control. Supernatants were collected 24 and $48 \mathrm{~h}$ posttransfection. Huh7.5 cells were then infected with serial dilutions of the virus-containing supernatants for $72 \mathrm{~h}$, and the median tissue culture infectious dose (TCID50) was calculated by measuring HCV-nonstructural protein (NS) 2 mRNA expression by quantitative RT-PCR (qRT-PCR) using the following primers: 5'-AGGGTATGCGCTTTGG-TGAA-3' (forward) and 5'-CCCAGTCCGACATAGGTGTG-3' (reverse).

\section{qRT-PCR analysis}

Total RNA was isolated from cells using the Tri Reagent (MilliporeSigma, Burlington, MA, USA) method. RNA yields were assessed using a NanoDrop ND-1000 spectrophotometer (Thermo Fisher Scientific). One microgram of total cell RNA was reverse-transcribed into cDNA using the SensiFast cDNA Synthesis Kit (Bioline) according to the manufacturer's instructions. PCR amplification was performed using primer specific pairs, as detailed in Table 1. Each reaction was carried out in duplicate using the following cycling parameters: $95^{\circ} \mathrm{C}$ for $15 \mathrm{~min}$ followed by 40 cycles of $92^{\circ} \mathrm{C}$ for $30 \mathrm{~s}, 65^{\circ} \mathrm{C}$ for $1 \mathrm{~min}$, and $72^{\circ} \mathrm{C}$ for $30 \mathrm{~s}$. All gene amplifications were normalized to $40 \mathrm{~S}$ ribosomal protein S15 (RPS15). Data analysis was carried out using the 2-DD comparative method.

\section{Immunoblotting}

Cells were harvested in radioimmunoprecipitation assay (RIPA) lysis buffer and supplemented with protease and phosphatase inhibitors $(1 \mathrm{mM}$ sodium orthovanadate, $1 \mathrm{mM}$ phenylmethylsulfonyl fluoride (PMSF), $5 \mu \mathrm{g} / \mathrm{ml}$ leupeptin) and $1 \mathrm{mM}$ dithiothreitol (DTT). Following $1 \mathrm{~h}$ incubation at $4^{\circ} \mathrm{C}$, extracts were pelleted at $12,000 \mathrm{~g}$ at $4^{\circ} \mathrm{C}$ for $10 \mathrm{~min}$. Sodium dodecyl sulfate (SDS) loading buffer was added and samples were boiled at $100^{\circ} \mathrm{C}$ for $7 \mathrm{~min}$. Equal quantities of lysate were resolved by SDS-polyacrylamide gel electrophoresis (PAGE), and proteins were transferred from the gel onto a Polyvinylidene fluoride

TABLE 1. Primers for PCR amplification

\begin{tabular}{lll}
\hline \hline & \multicolumn{2}{c}{ Forward } \\
\cline { 2 - 3 } Gene & \multicolumn{1}{c}{ Primer sequence, $5^{\prime}-3^{\prime}$} \\
\hline RPS15 & CGGACCAAAGCGATCTCTTC & \multicolumn{1}{c}{ Reverse } \\
CIS & GATCTGCTGTGCATAGCCAA & CGCACTGTACAGCTGCATCA \\
SOCS1 & CACTTCCGCACATTCCGTTC & ACAAAGGGCTGCACCAGTTT \\
SOCS2 & GAGCTCGGTCAGACAGGAT & AGGGGAAGGAGCTCAGGTA \\
SOCS3 & ATCCTGGTGACATGCTCCTC & CAGAGATGGTGCTGACGTGT \\
SOCS4 & CTTAGATCATTCCTGTGGGC & CAAATGTGCTTCCCCTTA \\
SOCS5 & TACAGCAAGCAGTCAAAGCC & ATGCCACCTAAAGGCTAAATC \\
SOCS6 & TCTCACCATTGCTACCTCCA & ACAGAGAAGAGGTAGTCCTC \\
SOCS7 & CTTCTCGGAAGGGCTCCTTC & GAGTCCCTGATTGAATGCTC \\
p7 GT1a & GGGAATCGGGCTTTGGAGAACCTCGTAA & AAGGCTGGCTGCAAAGCTGC \\
p7 GT2a & TTTCGTGGCTGCTTGGTACA & ATTTGTCGACTCATGCGTATGCCCGCTG \\
\end{tabular}


(PVDF) membrane. Primary antibodies were diluted 1:1000 in $5 \%(\mathrm{w} / \mathrm{v})$ Marvel in $1 \times$ Tris-buffered saline with Tween or $3 \%$ $(\mathrm{w} / \mathrm{v})$ bovine serum albumin and incubated overnight at $4^{\circ} \mathrm{C}$. Primary antibodies against SOCS3 (Abcam, Cambridge, MA, USA), SOCS4 (GeneTex, Irvine, CA, USA), SOCS5 (Santa Cruz Biotechnology, Dallas, TX, USA), phosphorylated STAT3 (Cell Signaling Technology, Danvers, MA, USA), total STAT3 (Santa Cruz Biotechnology), phosphorylated ERK1/2 (Cell Signaling Technology), total ERK1/2 (Cell Signaling Technology), phosphorylated STAT1 (Cell Signaling Technology), total STAT1 (Cell Signaling Technology), HA (Cell Signaling Technology), IкB- $\alpha$ (Prof. Ron Hay, University of Dundee, Dundee, United Kingdom), $\beta$-actin (MilliporeSigma), and secondary anti-mouse or anti-rabbit antibodies (Thermo Fisher Scientific) were used. Membranes were developed using enhanced chemiluminescent horse radish peroxidase substrate (Bio-Rad, Hercules, CA, USA) and analyzed using Image Lab software from Bio-Rad.

\section{Luciferase reporter gene assays}

Huh7 cells were plated onto 6-well plates at a density of $2.5 \times 10^{5}$ cells per ml. After $24 \mathrm{~h}$, cells were transfected using Lipofectamine 2000 with NF-кB firefly luciferase reporter construct $(1 \mu \mathrm{g})$, GAS firefly luciferase reporter construct $(1 \mu \mathrm{g})$, or positive regulatory domain (PRD)IV (AP-1) firefly luciferase reporter construct $(1 \mu \mathrm{g})$ (a kind gift from Dr. Andrew MacDonald, Leeds University, Leeds, United Kingdom) (59), constitutively expressed pGL3 luciferase reporter construct, and HCV-p7-HA $(1 \mu \mathrm{g})$, pCMV-HA $(1 \mu \mathrm{g})$, Flag-TRAF6 $(1 \mu \mathrm{g})$, or Flag-TRAF2 $(1 \mu \mathrm{g})$. The activation of ELK1 was determined using Gal4-firefly luciferase reporter plasmid pFR-luciferase $(1 \mu \mathrm{g})$ with the transactivator plasmid pFA-ELK1 (activation domain of ELK is fused with the yeast GAL4 DNA binding domain) $(1 \mu \mathrm{g})$, pGL3 $(1 \mu \mathrm{g})$, and either HCV-p7-HA $(1 \mu \mathrm{g})$ or pCMV-HA control $(1 \mu \mathrm{g})$. Cells were treated with $10 \mathrm{ng} / \mathrm{ml}$ of TNF- $\alpha, 1000 \mathrm{IU} / \mathrm{ml}$ of IFN- $\alpha$, $50 \mathrm{ng} / \mathrm{ml}$ of LPS, or $50 \mathrm{ng} / \mathrm{ml}$ of PMA for $24 \mathrm{~h}$. Cell extracts were generated $24 \mathrm{~h}$ posttreatment using reporter lysis buffer (Promega, Madison, WI, USA), and extracts were assayed for firefly luciferase and Renilla luciferase activity using the luciferase assay system (Promega) and coelenterazine (Thermo Fisher Scientific), respectively. Firefly luciferase values were normalized to Renilla values, and data shown are the means \pm SEM of at least 3 independent experiments in triplicate.

\section{Confocal}

Huh7 cells were seeded on poly-L-lysine coated cover slips for $24 \mathrm{~h}$ prior to transfection. Cells were fixed in $4 \%$ paraformaldehyde for $20 \mathrm{~min}$, permeabilized in $0.5 \%$ Triton X-100 for $15 \mathrm{~min}$, and blocked with $5 \%$ bovine serum albumin in PBS-Tween $(0.05 \%)$ for $1 \mathrm{~h}$. The cells were then stained with 1:500 anti-HA (Covance, Princeton, NJ, USA) or anti-calnexin (Santa Cruz Biotechnology) overnight at $4^{\circ} \mathrm{C}$. The cells were then stained with 1:1000 anti-mouse-Alexa Fluor 594 and anti-rabbit-Alexa Fluor 488 (Thermo Fisher Scientific) and 1:500 DAPI. The cover slips were then mounted in ProLong Antifade Reagent (Thermo Fisher Scientific) before being visualized using the Olympus Fluoview confocal microscope and analyzed using the Olympus Fluoview FV10-ASW software (Olympus, Tokyo, Japan).

\section{Statistical analysis}

Statistical analysis was carried out using GraphPad Prism version 6 for Mac (GraphPad Software, La Jolla, CA, USA). Statistical analysis was performed using unpaired Student's $t$ test assuming Gaussian distribution. A value of $P<0.05$ was deemed statistically significant.

\section{RESULTS}

\section{HCV-p7 (GT1a) enhances SOCS3 mRNA and protein expression}

Having previously observed that HCV polyprotein expression induced SOCS3 (19), to determine which specific region of $\mathrm{HCV}$ was responsible for this immune regulatory effect, we analyzed the effect of the first nonstructural $\mathrm{HCV}$ protein, $\mathrm{p} 7$, upon the entire SOCS family of genes. Huh7 cells were transfected with p7 or EV control for $24 \mathrm{~h}$ before total RNA was analyzed for p7 and CIS-SOCS7 mRNA by qRT-PCR. SOCS3 (Fig. 1E), SOCS4 (Fig. 1F), and SOCS5 (Fig. 1G) mRNA were significantly induced upon the expression of $\mathrm{p} 7$ (Fig. 1A). In contrast, $\mathrm{p} 7$ had no significant effect upon CIS (Fig. 1B), SOCS1 (Fig. 1C), SOCS2 (Fig. 1D), SOCS6 (Fig. 1H), or SOCS7 (Fig. 1I) mRNA levels. Having observed a statistically significant induction of SOCS3, SOCS4, and SOCS5 mRNA upon p7 expression, we next analyzed if their mRNA induction was translated to protein by immunoblotting lysates with the SOCS3-5 antibodies. We found that p7 enhanced SOCS3 protein expression compared with EV control (Fig. 2A). Quantitative densitometry analysis revealed SOCS3 induction by $\mathrm{p} 7$ was statistically significant (Fig. 2B). However, when we analyzed SOCS4 and SOCS5 protein, we observed high basal expression of both proteins that did not change upon $\mathrm{p} 7$ expression (Fig. 2C, E). Indeed, densitometry analysis confirmed that neither SOCS4 nor SOCS5 protein expression was significantly altered by $\mathrm{p} 7$ (Fig. 2D, F). In summary, we found that $p 7$ expression did not affect CIS, SOCS1, SOCS2, SOCS6, or SOCS7 mRNA; however, although this viral protein significantly induced SOCS3-5 mRNA, only the induction of SOCS3 mRNA by p7 was mirrored at the protein level. Therefore, because SOCS3 was the only SOCS protein to be increased by $\mathrm{p} 7$, it is likely to be the only family member to have a functional impact upon immune signaling.

To confirm that the HA tag of the p7-HA construct was not responsible for the SOCS3 induction, we next expressed a construct in HEK293T cells encoding an untagged p7 before analyzing SOCS3 levels. We observed that $\mathrm{p} 7$ alone induced SOCS3 mRNA and protein expression (Supplemental Fig. $\mathrm{S} 1 A, C, D)$. We also confirmed the expression of $\mathrm{p} 7 \mathrm{in}$ these cells by measuring 7 mRNA (Supplemental Fig. S1B).

Because $\mathrm{p} 7$ localizes to intracellular membranes, such as the endoplasmic reticulum (ER), we next analyzed, by confocal microscopy, the intracellular location of our p7HA. Indeed, we observed that our p7-HA colocalized with the ER marker calnexin (a molecular chaperone that locates at the ER) (Supplemental Fig. S2), confirming its predicted location.

\section{HCV-p7 inhibition reduces induction of SOCS3}

Having identified that the expression of $\mathrm{p} 7$ led to an increase in SOCS3, we next used a p7 inhibitor, NNDNJ, to 
A

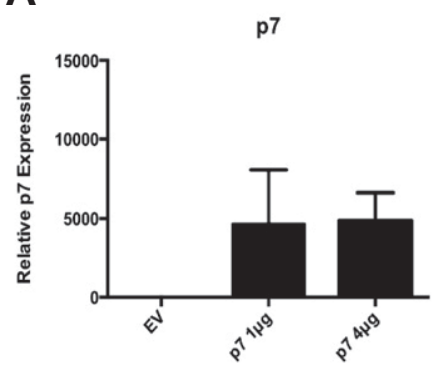

D

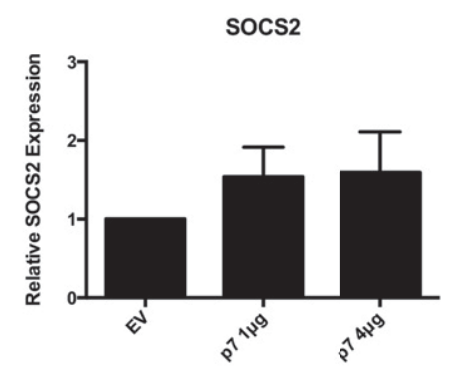

G

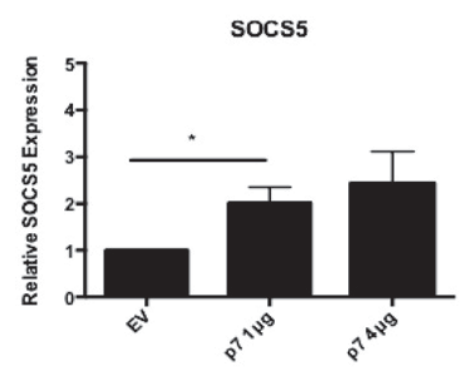

B

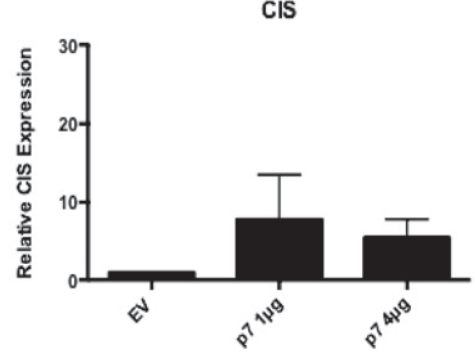

E

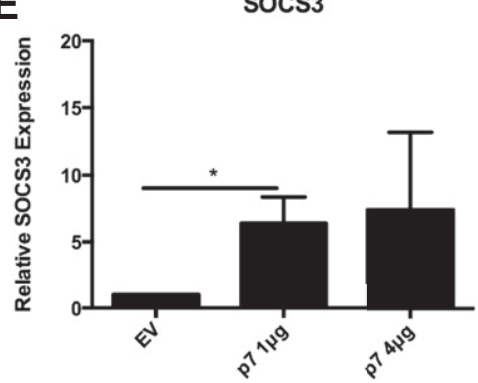

H

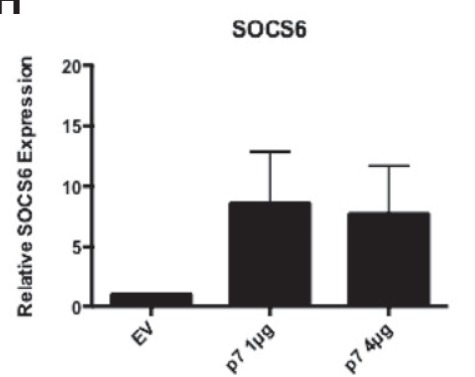

C

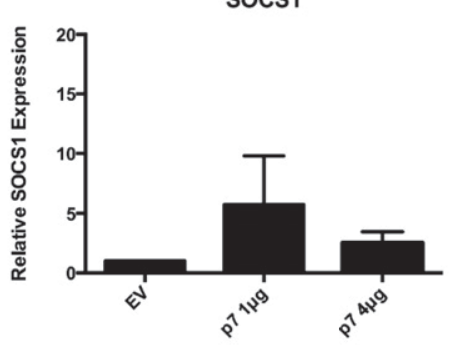

F

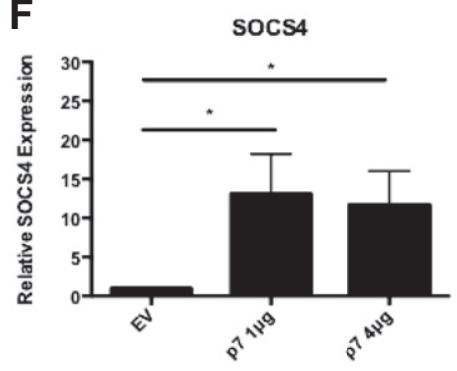

I

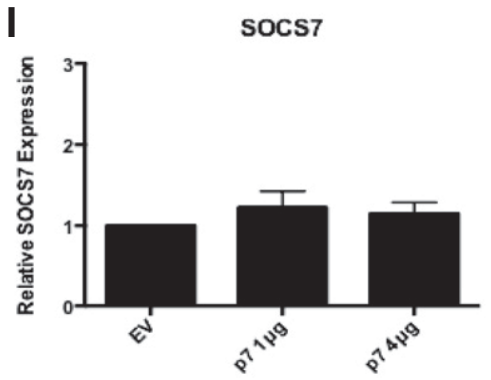

Figure 1. HCV-p7 expression induced SOCS3, SOCS4, and SOCS5 mRNA. Huh7 cells were transfected with 1 or $4 \mu \mathrm{g}$ of DNA encoding HCV-p7-HA or EV control, and mRNA levels of p7 $(A)$, CIS $(B)$, SOCS1 $(C)$, SOCS2 $(D)$, SOCS3 $(E)$, SOCS4 $(F)$, SOCS5 $(G)$, SOCS6 $(H)$, and SOCS7 $(I)$ were analyzed after $24 \mathrm{~h}$ by qRT-PCR. Results are the means \pm sEM of 7 independent experiments. Gene values were calculated relative to the housekeeping control, and p7-expressing cells are displayed relative to EV controls, which were normalized to $1 .{ }^{*} P<0.05$ (Student's $t$ test).

investigate if its ion channel activity was responsible for this induction. HEK293T cells were transfected with $\mathrm{p} 7$ or EV control for $16 \mathrm{~h}$ prior to an 8-h treatment with 20 or $100 \mu \mathrm{M}$ of NNDNJ. Cells were lysed and SOCS3 expression was analyzed by immunoblotting. We found that treatment with $100 \mu \mathrm{M}$ of NNDNJ decreased SOCS3 expression in p7-transfected samples compared with EV control (Fig. 3), indicating that p7 ion channel activity may be required for SOCS3 induction.

\section{GT2a HCV-p7 promotes SOCS3 induction}

Having identified that GT1a p7 expression induced SOCS3, we next analyzed if this was genotype specific by transfecting Huh7 cells with HCV GT2a p7 or the empty WPI_BLR vector. As with p7 GT1a, we found that p7 GT2a also enhanced SOCS3 protein expression (Fig. 4A). Densitometric analysis of the experimental repeats confirmed significantly up-regulated SOCS3 in p7 GT2a-expressing Huh7 hepatocytes (Fig. 4B). The expression of $\mathrm{p} 7$ in these cells was also confirmed by measuring mRNA levels of $p 7$ GT2a (Fig. 4C). HEK293T cells were also transfected with 1 or $4 \mu \mathrm{g}$ of GT2a p7-HA. Similar to our finding in Huh7 cells, the expression of p7 GT2a in HEK293T cells enhanced SOCS3 protein expression (Supplemental Fig. S3A). Densitometric analysis of the experimental repeats confirmed significantly up-regulated SOCS3 in cells transfected with $4 \mu \mathrm{g}$ of GT2a p7-HA (Supplemental Fig. $\mathrm{S} 3 B$ ). These results suggest that $\mathrm{p} 7$ uses a conserved mechanism of SOCS3 up-regulation across HCV GT1a and GT2a.

\section{Replicating HCV (JC1) induces SOCS3 partially through p7}

Having identified that the individual $\mathrm{p} 7$ protein induced SOCS3, we next investigated the role of $\mathrm{p} 7$ in the context of HCV infection. Specifically, we infected highly permissive Huh7.5 cells with the chimeric HCV genome Jc1, a hybrid of J6CF and JFH1, or Jc1 $1 \Delta \mathrm{p} 7$ before analyzing SOCS3 mRNA induction by qRT-PCR. We observed that infection with full-length Jc1 significantly induced SOCS3; however, this significance was lost upon infection with Jc1 $1 \Delta \mathrm{p} 7$ (Fig. 4D, E). Interestingly, SOCS3 was partially (although not significantly) induced by Jc1 $1 \Delta \mathrm{p} 7$; this was of no 


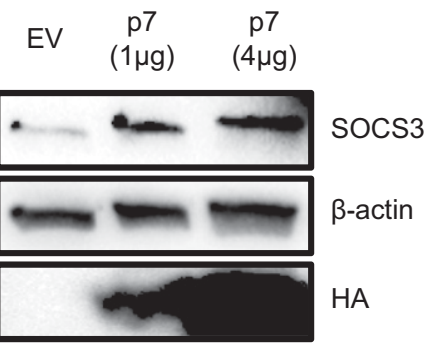

C

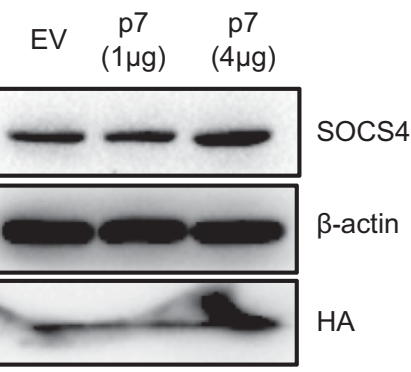

$\mathbf{E}$

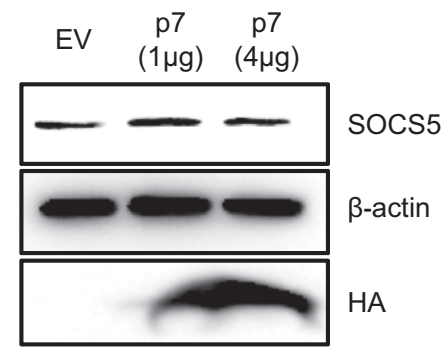

B

socs3

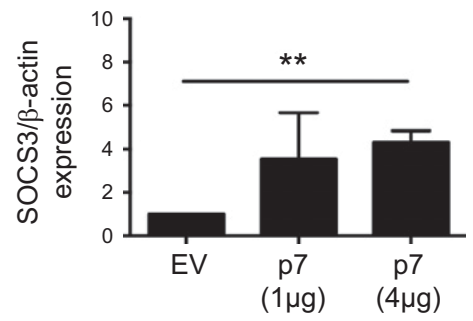

D

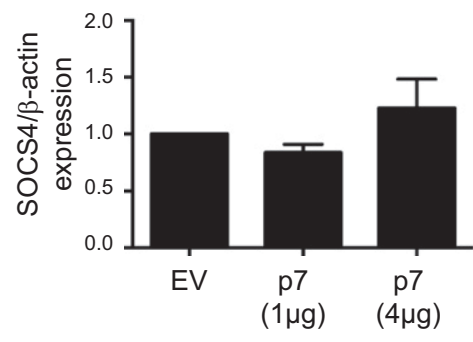

$\mathbf{F}$

SOCS5

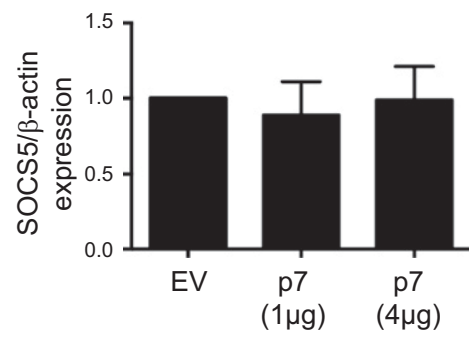

Figure 2. HCV-p7 increases SOCS3, but not SOCS4 or SOCS5, protein expression. $A, C, E$ ) Huh7 cells were transfected with 1 or $4 \mu \mathrm{g}$ of DNA encoding HCV-p7-HA or EV control for $24 \mathrm{~h}$ before lysates were analyzed for SOCS3 $(A)$, SOCS4 $(C)$, SOCS5 $(E), \beta$-actin, and p7 (HA) by Western blotting. Blots are representative of 3 independent experiments. $B, D, F)$ Densitometric analysis of 3 Western blots was performed using Image Lab. Bar graph illustrates the mean \pm SEM increase in SOCS3 $(B)$, SOCS4 $(D)$, or SOCS5 $(F)$ expression relative to $\beta$-actin and compared with EV control, which was normalized to 1 . $* * P<0.01$ (Student's $t$ test). surprise, because HCV core (which is present in both our Jc1 and Jc1 $1 \Delta \mathrm{p} 7$ constructs) has previously been shown to also induce SOCS3 $(28,60)$; furthermore it is also possible that the remaining region of $p 7$ could be involved in the induction of SOCS3. Indeed, it has also been reported that HCV E2 up-regulates SOCS3 expression (29). These findings support our initial observations that $\mathrm{p} 7 \mathrm{can}$ induce SOCS3.

\section{HCV-p7-mediated STAT3 activity induces SOCS3}

Because SOCS3 is classically known to be induced by STAT3 (61), we hypothesized that STAT3 might have a significant role in p7-mediated induction of SOCS3. To test this hypothesis, we first investigated the effect of p7 expression upon STAT3 tyrosine phosphorylation. Huh7 cells were transfected with $\mathrm{p} 7$ or EV control for $12 \mathrm{~h}$, and STAT3 phosphorylation was measured by immunoblotting. We observed that STAT3 phosphorylation was enhanced after $12 \mathrm{~h}$ of $\mathrm{p} 7$ expression (Fig. $5 \mathrm{~A}$ ). In addition, we also found that $\mathrm{p7}$ expression had no effect on STAT1 phosphorylation after $12 \mathrm{~h}$ (Supplemental Fig. S4). Having observed p7-mediated STAT3 phosphorylation, we next investigated if this effect was passed downstream to the GAS promoter, which is driven by STAT3 homodimers (12,
62). We observed that expression of p7 in Huh7 cells significantly induced GAS reporter activity compared with $\mathrm{EV}$; in fact, p7-mediated GAS promoter activity was as strong as that observed in IFN- $\alpha$-treated control cells (Fig. $5 B$ ). In contrast to GAS, there was no significant induction of ISRE (Fig. 5C). This result was not surprising, because ISRE activity requires binding of the STAT1-STAT2-IFN regulatory factor (IRF)9, ISG factor (ISGF) 3 complex (63, 64).

Having discovered that $\mathrm{p} 7$ could induce both phosphorylated STAT3 and GAS activity, we next investigated if STAT3 was essential for p7-mediated induction of SOCS3. HEK293T cells were transfected with STAT3 shRNA or control shRNA for $24 \mathrm{~h}$ prior to 24 -h transfection of HCV-p7 or EV control. We found that by significantly reducing STAT3 protein levels (via shRNA knockdown) (Fig. 6A, B), induction of SOCS3 upon p7 expression was no longer possible (Fig. 6A). Furthermore, densitometric analysis confirmed that the statistical significance of $\mathrm{p} 7$ mediated induction of SOCS3 protein was lost in the absence of STAT3 (Fig. 6C). Collectively, because STAT3 is classically known to be required for SOCS3 induction (61), these data suggest that STAT3 and its subsequent phosphorylation are also required for $\mathrm{p} 7$-mediated induction of SOCS3, possibly revealing a mechanism by which HCV up-regulates this inhibitory protein. 
Figure 3. p7 induction of SOCS3 is blocked by the NNDNJ p7 inhibitor. A) HEK293T cells were transfected with $1 \mu \mathrm{g}$ of DNA encoding HCV-p7-HA or EV control for $16 \mathrm{~h}$, followed by treatment with 20 or $100 \mu \mathrm{M}$ of NNDNJ for $8 \mathrm{~h}$. Cells were harvested, and lysates were probed for SOCS3, $\beta$-actin, and HA (p7). Blots shown are representative of 3 independent experiments. B) Densitometric analysis of 3 Western blots was performed using Image Lab; the bar graph illustrates the mean \pm SEM increase in SOCS3 relative to $\beta$-actin and compared with EV control, which was normalized to 1 ; ns, not significant. $* P<0.05$ (Student's $t$ test).
A

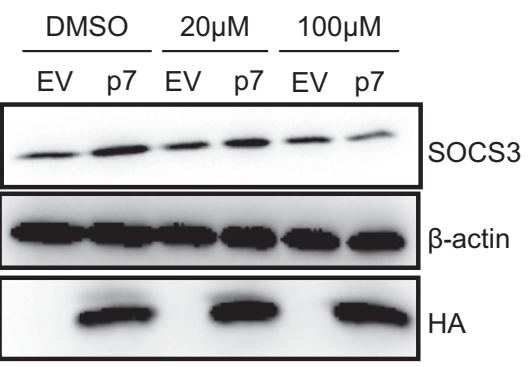

B

socs3

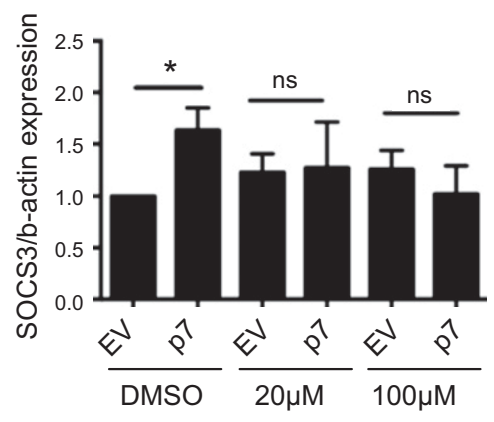

\section{HCV-p7-mediated ERK activity induces SOCS3}

Because MAPK signaling also regulates SOCS3 expression (65), we wondered if ERK signaling might also be involved in p7 induction of SOCS3. Therefore, we initially analyzed the effect of p7 on ERK phosphorylation by transfecting Huh7 cells with $\mathrm{p} 7$ or EV control for $24 \mathrm{~h}$ and subjecting lysates to immunoblotting for ERK, total ERK, $\beta$-actin and p7 (HA). We discovered that expression of p7 enhanced ERK phosphorylation compared with EV control (Fig. 7A). To further investigate the effects of $\mathrm{p} 7$ upon the MAPK pathway, we also measured the promoter activity of 2 known transcription factors downstream of ERK: AP-1 and ELK1 $(66,67)$. We found that p7 significantly enhanced the promoter activity of both AP-1 and ELK1 compared with EV control (Fig. 7B, C). Having observed that $\mathrm{p} 7$ could induce both phosphorylated ERK- and ERK-driven promoter activity, we next investigated if MAPK signaling was directly involved in p7-induced SOCS3 by inhibiting MEK, which is upstream of ERK. Huh7 cells were pretreated with the MEK inhibitor, PD98059, for $45 \mathrm{~min}$, prior to $24 \mathrm{~h}$ transfection of p7 or EV control. Our immunoblotting and densitometric analysis indicated that MEK inhibition dampened p7-mediated induction of SOCS3 protein (Fig. 8), further suggesting that expression of $\mathrm{p} 7$ enhances MAPK ERK signaling, which also may lead to SOCS3 induction.

\section{HCV-p7 inhibits proinflammatory TNF- $\alpha$ signal transduction}

We previously reported that HCV-induced SOCS3 regulated proinflammatory TNF- $\alpha$ signaling (19); therefore, we next investigated if p7's induction of SOCS3 could also inhibit TNF- $\alpha$ signal transduction. Huh7 cells were
Figure 4. HCV GT2a p7 induces SOCS3. Huh7 cells were transfected with $1 \mu \mathrm{g}$ p7 GT2a or EV control for $24 \mathrm{~h}$. A) Cells were harvested, and lysates were probed for SOCS3 and $\beta$-actin. Blots shown are representative of 3 independent experiments. B) Densitometric analysis of 3 Western blots was performed using Image $\mathrm{Lab}$; the bar graph illustrates the mean \pm SEM increase in SOCS3 relative to $\beta$-actin and compared with EV control, which was normalized to 1 . C) mRNA levels of p7 were analyzed by qRT-PCR. Results are the means \pm SEM of 3 independent experiments. Gene values were calculated relative to the housekeeping control, and p7-expressing cells are displayed relative to $\mathrm{EV}$ controls, which were normalized to $1 . D, E$ ) Huh7.5 cells were mock infected or infected with $\mathrm{Jc} 1$ or $\mathrm{Jc} 1 \Delta \mathrm{p} 7$ for $72 \mathrm{~h}$, and mRNA levels of SOCS3 $(D)$ and p7 $(E)$ were analyzed by qRT-PCR. Results are the means \pm SEM of 4 independent experiments. Gene values were calculated relative to the housekeeping control RPS15, and HCV-infected cells are displayed relative to mock infected controls, which were normalized to 1 ; ns, not significant. $* P<0.05$ (Student's $t$ test).

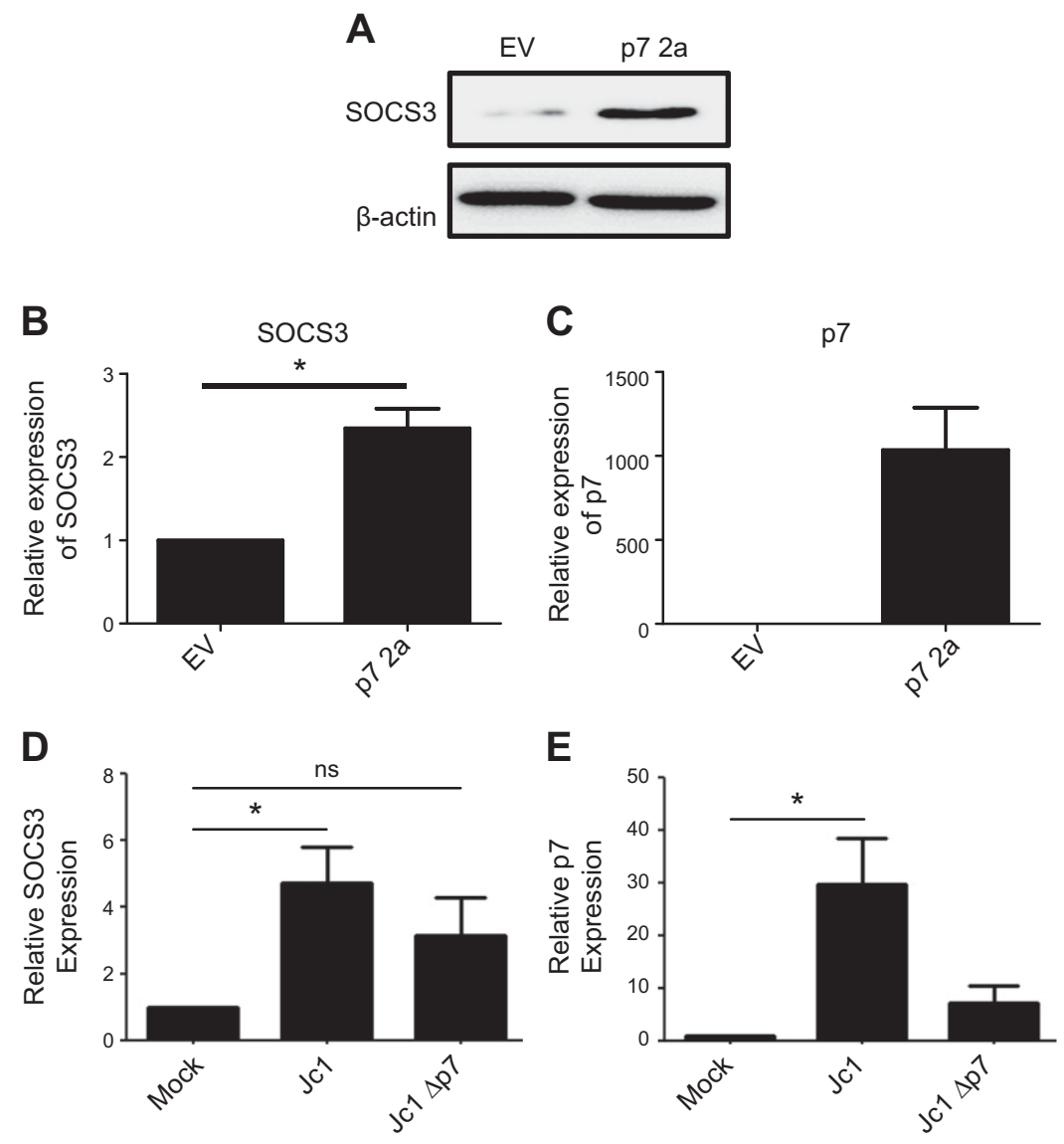

A

B
E 

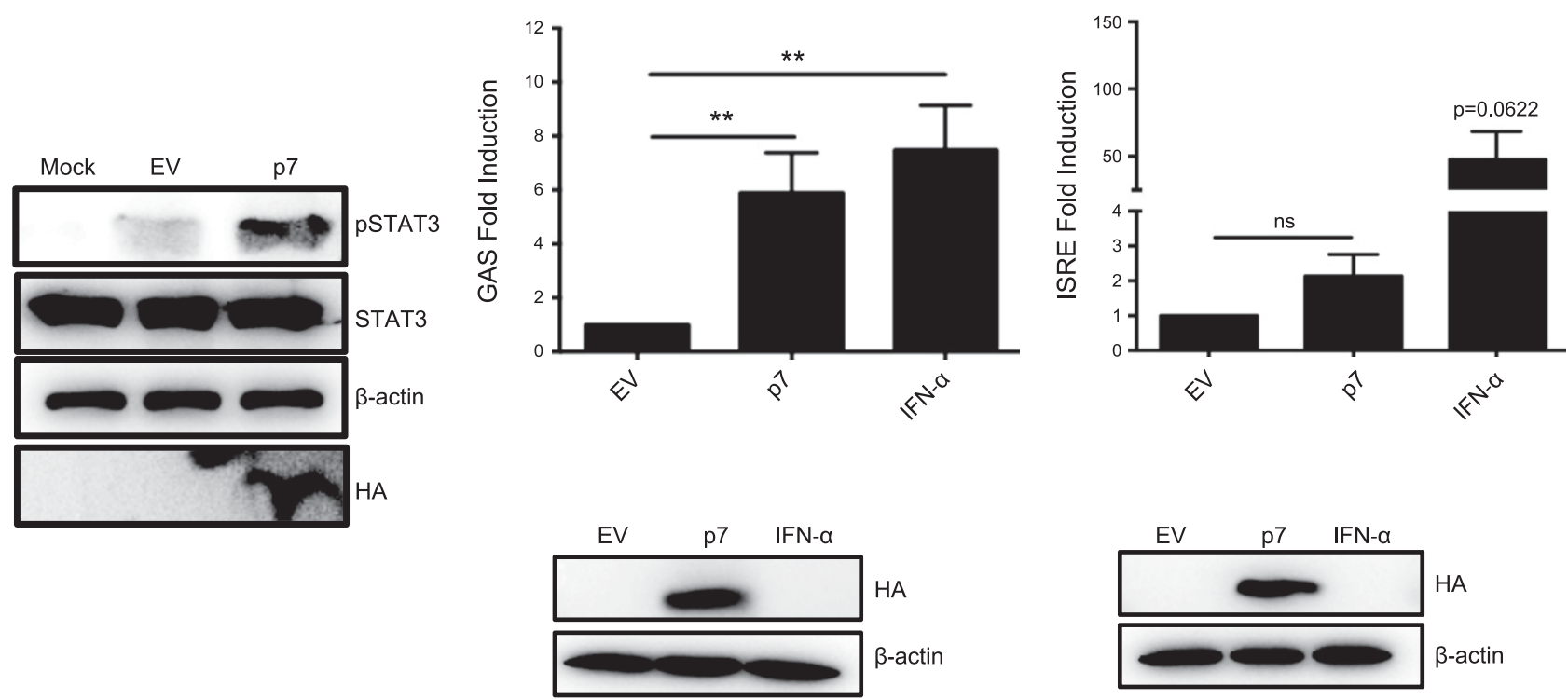

Figure 5. HCV-p7 induces STAT3 phosphorylation and GAS activity. A) Huh7 cells were transfected with DNA encoding HCV-p7HA or EV control $(1 \mu \mathrm{g})$ for $12 \mathrm{~h}$, and lysates probed for phosphorylated STAT3 (pSTAT3), total STAT3, $\beta$-actin, and HA. Blots are representative of 3 independent experiments. $B, C$ ) Huh7 cells were transfected with plasmids encoding GAS-regulated firefly luciferase $(1 \mu \mathrm{g})(B)$ or ISRE-regulated firefly luciferase $(1 \mu \mathrm{g})(C)$, along with constitutively expressed pGL3 Renilla luciferase $(1 \mu \mathrm{g})$ in the presence of DNA encoding HCV-p7-HA or EV control $(1 \mu \mathrm{g})$ for $24 \mathrm{~h}$. Cells were then treated with IFN- $\alpha$ for $24 \mathrm{~h}$. Cell lysates were assayed for firefly luciferase activity and normalized for transfection efficiency using pGL3 Renilla luciferase activity. p7 (HA) expression and $\beta$-actin control were confirmed by Western blotting. Results shown are the means \pm sEM of 7 (GAS) and 4 (ISRE) independent experiments in triplicate and analyzed by Student's $t$ test; ns, not significant. $* * P<0.01$.

transfected with EV control or $\mathrm{p} 7$ for $24 \mathrm{~h}$ prior to stimulation with TNF- $\alpha$ for $20 \mathrm{~min}$. TNF- $\alpha$-mediated NF-кB signaling was subsequently measured by immunoblotting for IкB- $\alpha$ protein degradation. We found that $\mathrm{p} 7$ blocked normal TNF- $\alpha$-mediated ІкB- $\alpha$ degradation (Fig. 9A), and densitometric analysis confirmed that the statistically significant degradation of IкB- $\alpha$ was lost in the presence of $\mathrm{p} 7$ (Fig. 9B). To further analyze the effect of p7 upon NF-кB signal transduction, we next analyzed the effect of $\mathrm{p} 7$ upon NF-kB-dependent reporter activity. Huh7 cells were cotransfected with $1 \mu \mathrm{g}$ of NF-кB-regulated firefly luciferase and $1 \mu \mathrm{g}$ of constitutively expressed pGL3 Renilla, in the presence of $1 \mu \mathrm{g}$ of either p7, EV control, or FlagTRAF6. After $24 \mathrm{~h}$, cells were stimulated with $20 \mathrm{ng}$ of TNF- $\alpha$ for $24 \mathrm{~h}$. Cells were harvested and assayed for firefly and Renilla luciferase activity after $48 \mathrm{~h}$. In agreement with our IкB- $\alpha$ protein analysis, we found that overexpression of $p 7$ significantly inhibited TNF- $\alpha-$ induced NF-кB promoter activity compared with control cells (Fig. 9C). In addition, we also investigated the effect

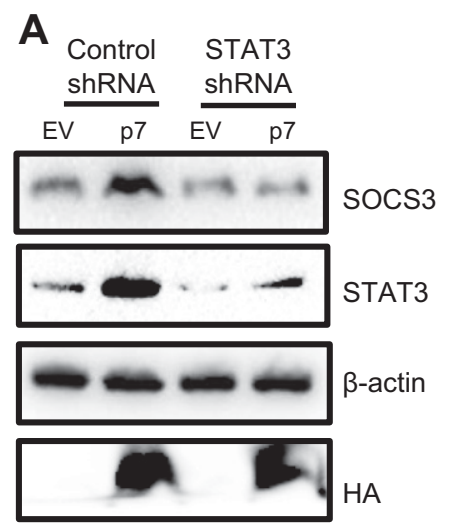

B

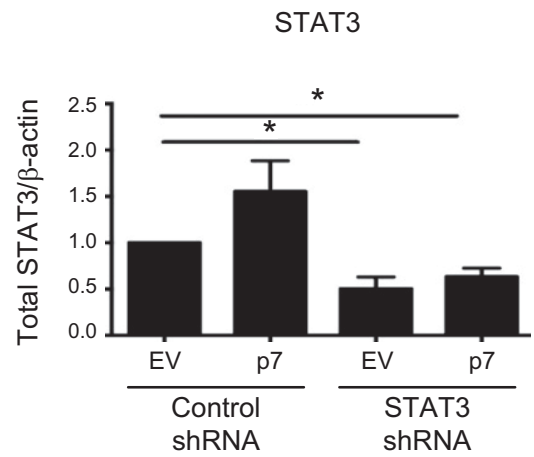

C

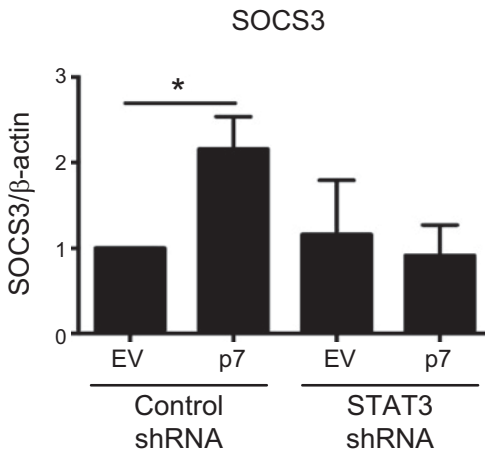

Figure 6. STAT3 is required for p7-mediated SOCS3 induction. A) HEK293T cells were transfected with $1 \mu \mathrm{g}$ of STAT3 shRNA or control for $24 \mathrm{~h}$ prior to transfection with $1 \mu \mathrm{g}$ of DNA encoding HCV-p7-HA or EV control for $24 \mathrm{~h}$. Lysates were probed for STAT3, SOCS3, $\beta$-actin, and HA (p7). Blots shown are representative of 3 independent experiments. $B$, $C$ ) Densitometric analysis of 3 Western blots was performed using Image Lab. Bar graphs illustrate the means \pm SEM of STAT3 (B) and SOCS3 ( $C$ ) expression calculated against $\beta$-actin housekeeping control and displayed relative to EV control, which was normalized to 1. Data were analyzed by Student's $t$ test. $* P<0.05$. 

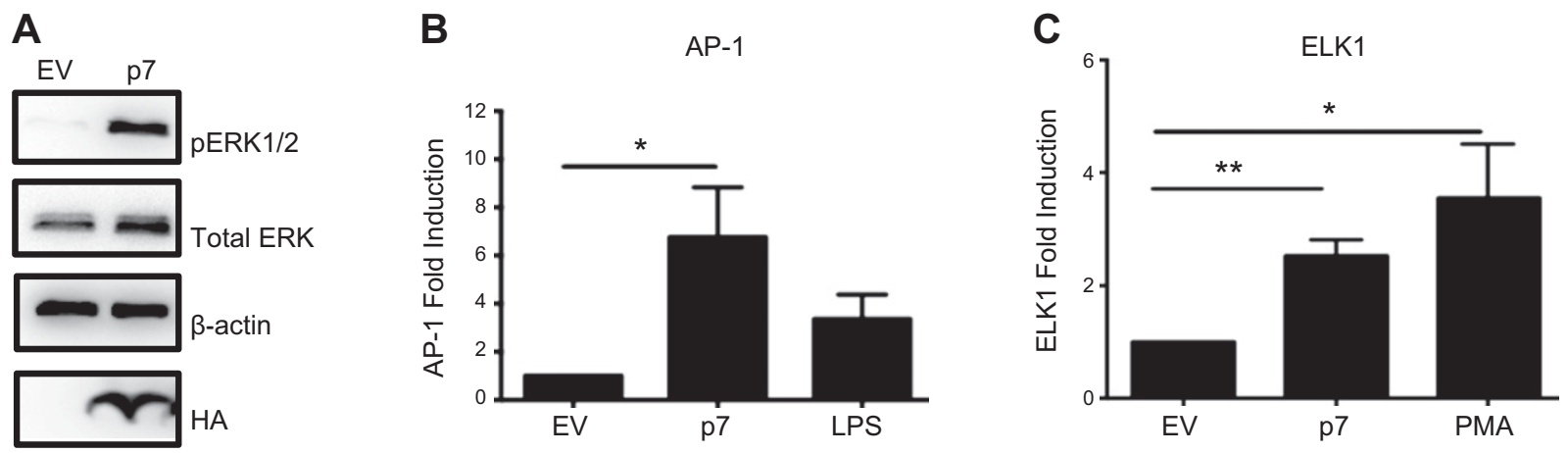

Figure 7. HCV-p7 induces ERK phosphorylation and drives AP-1 and ELK1 promoter activity. A) Huh7 cells were transfected with $1 \mu \mathrm{g}$ of DNA encoding HCV-p7-HA or EV control for $24 \mathrm{~h}$. Cells were harvested, and lysates were probed for phosphorylated ERK1/2 (pERK1/2), total ERK 1/2, $\beta$-actin, and HA (p7). Blots shown are representative of 3 independent experiments. $B$, $C$ ) Huh7 cells were transfected with constitutively expressed pGL3 Renilla luciferase (1 $\mu \mathrm{g})$, DNA encoding HCV-p7-HA, or EV control in the presence of PRDIV (AP-1)-regulated firefly luciferase $(B)$ or pFA-ELK1 $(1 \mu g)(C)$ and pFR-regulated firefly luciferase $(1 \mu \mathrm{g})$. Transfected cells were left overnight and then treated with $100 \mathrm{ng}$ of LPS or $100 \mathrm{ng}$ of PMA for $24 \mathrm{~h}$. Cell lysates were assayed for firefly luciferase activity and normalized for transfection efficiency using pGL3 Renilla luciferase activity. Results shown are the means \pm SEM of 3 (AP-1) and 4 (ELK1) independent experiments in triplicate and analyzed by Student's $t$ test. $* P<0.05, * * P<0.01$.

of $\mathrm{p} 7$ on both TRAF2- and TRAF6-mediated NF-кBdependent reporter activity. HEK293T cells were cotransfected with $1 \mu \mathrm{g}$ of NF-kB-regulated firefly luciferase and $1 \mu \mathrm{g}$ of pGL3 Renilla in the presence of $1 \mu \mathrm{g}$ of either Flag-TRAF2, Flag-TRAF6, p7, or EV control. Cells were harvested after $48 \mathrm{~h}$ for firefly and Renilla luciferase activity. We also observed that $\mathrm{p} 7$ expression reduced both TRAF2- and TRAF6-induced NF-кB promoter activity (Supplemental Fig. S5). Taken together, these results strongly suggest that $\mathrm{p} 7$ regulates TNF- $\alpha$-mediated NF$\kappa \mathrm{B}$ activation, thus pointing towards a new and specific role for $\mathrm{p} 7$ in controlling inflammatory signaling.

\section{DISCUSSION}

SOCS proteins are critical negative regulators of cytokine and growth factor signaling, required to switch off signaling cascades, which, if unregulated, could have pathologic consequences (68). Many viruses have hijacked this mechanism to dampen innate antiviral activity (27). Interestingly, clinicians have long reported that HCV infection has mild pathology, resulting in the virus going undetected in many patients until liver disease presents its own clinical symptoms (69). The lack of inflammatory symptoms, associated with normal viral infection, suggests that HCV has developed mechanisms to suppress the host innate antiviral immune response. Indeed, $\mathrm{HCV}$ has evolved multiple strategies of evasion, enabling the silent progression of disease (70). Our laboratory previously discovered that PBMCs from patients infected with HCV had significantly enhanced SOCS3 levels compared with healthy controls and that HCV-mediated SOCS3 induction inhibited proinflammatory TNF- $\alpha$ signaling in Huh7 cells (19). Therefore, the mechanism of SOCS3 upregulation warranted further investigation.

Here, we show that HCV-p7 significantly induced SOCS3 mRNA and protein expression. Moreover, we also report that infection of Huh7.5 cells with Jc1 HCV virus significantly up-regulated SOCS3 mRNA expression and that this significance was lost following infection with Jc1 $1 \Delta \mathrm{p} 7$. We observed that SOCS3 was partially induced by $\mathrm{Jc} 1 \Delta \mathrm{p} 7$; however, because Jc1 $1 \Delta \mathrm{p}$ is a partial deletion, the remaining section of p7 may be inducing some SOCS3; furthermore, because the HCV core (28) and E2 (29) proteins are known to also up-regulate SOCS3, they may also account for the partial increase in SOCS3. Because p7 can affect several cellular processes, including membrane permeability and ion flux, future studies using $\mathrm{p} 7$ mutants should analyze the specific role of these processes in SOCS3 induction. Because SOCS3 induction is associated with STAT3 activity (36), we speculated that STAT3 might be important for the up-regulation of SOCS3 expression. Because STAT3 phosphorylation is required for propagation of its pathway (71), we first investigated the effect of p7 upon phosphorylated STAT3. We found that STAT3 phosphorylation was enhanced following 7 expression; indeed, downstream GAS luciferase activity was also significantly up-regulated. Taken together, these results indicate that in the presence of p7, STAT3 activity was increased and that this may have led to functional promoter activity.

Interestingly, when STAT3 was suppressed by shRNA, p7 expression no longer enhanced SOCS3 levels, further indicating that STAT3 is essential for p7-mediated SOCS3 induction. Indeed, our results are in line with several studies showing that STAT3 deletion prevents SOCS3 induction. Baker et al. (65) illustrated that oncostatin M stimulation leads to the robust recruitment of STAT3 to the SOCS3 promoter and that small interfering RNAmediated STAT3 inhibition prevented SOCS3 induction. Additionally, overexpression of STAT3 dominant negative mutants inhibited leukemia inhibitory factormediated SOCS3 expression (72). Previous studies have reported that HCV infection modulates STAT3 signaling, including STAT3 activation by the core and NS5A viral proteins $(73,74)$, in addition to oxidative stress-induced 
A

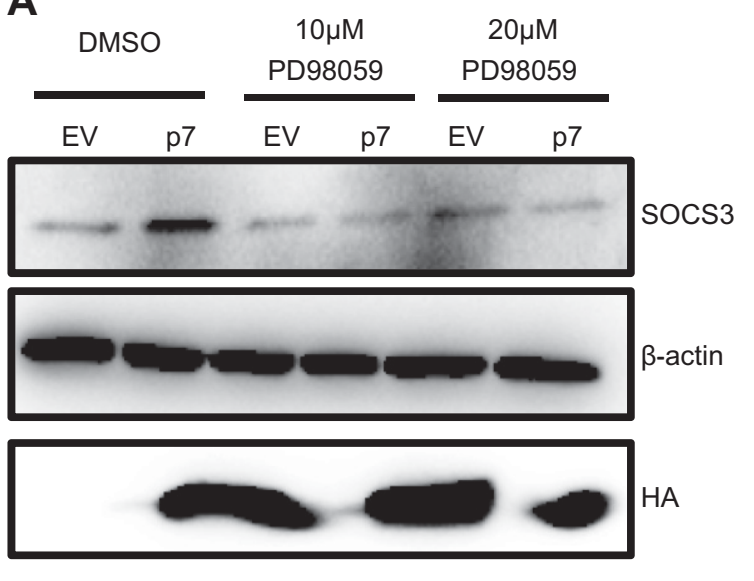

B

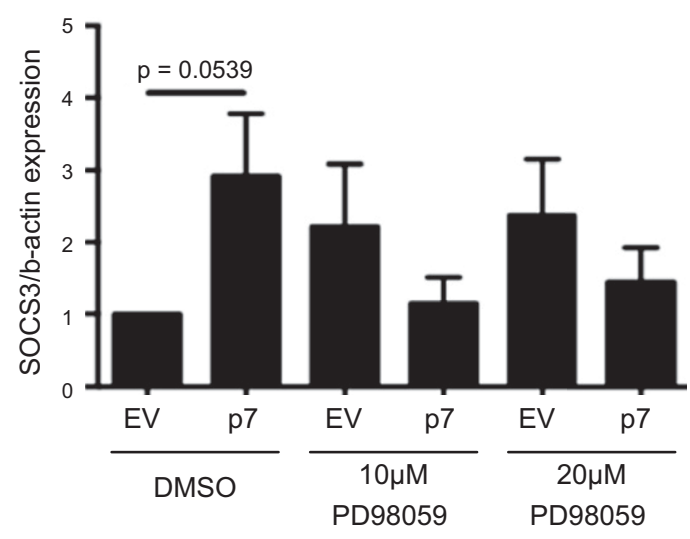

Figure 8. MEK activity is required for p7-mediated SOCS3 induction. A) Huh7 cells were pretreated with 10 or $20 \mu \mathrm{M}$ of PD98059 for $45 \mathrm{~min}$ prior to $24 \mathrm{~h}$ transfection with DNA encoding $1 \mu \mathrm{g}$ HCV-p7-HA or EV control. Lysates were probed for SOCS3, $\beta$-actin, and HA. Blots shown are representative of 5 independent experiments. B) Densitometric analysis of 5 Western blots was performed using Image Lab. The bar graph illustrates the mean \pm SEM of SOCS3 expression calculated against $\beta$-actin control and displayed relative to DMSO-EV control, which was normalized to 1 .

STAT3 activation by HCV replication (75). Interestingly, NS4B causes ER stress, which activates STAT3 signaling, leading to the induction of STAT3-dependent genes, including vascular endothelial growth factor (VEGF), c-Myc, and matrix metalloproteinase (MMP)9 (76). Furthermore, McCartney et al. (77) showed that STAT3 is actively phosphorylated in the presence of HCV and that STAT3 knockdown significantly decreases HCV RNA levels, implicating STAT3 as a proviral host factor. Together these findings indicate that STAT3 signaling is important for $\mathrm{HCV}$ infection, and our discovery, that $\mathrm{p} 7$ modulates STAT3 expression and activation, is in keeping with these published reports. STAT1 is also reported to regulate SOCS3 transcription (72); however, in contrast, we did not observe STAT1 phosphorylation upon p7 expression in Huh7 cells, indicating that unlike STAT3, STAT1 may not be required for $\mathrm{p} 7$-induced SOCS3.

In addition to STAT3 induction of SOCS3, MAPK signaling is also known to regulate SOCS3 expression
$(52,54,65,78)$. Furthermore, HCV infection has been documented to modify MAPK signaling, including HCV core and E2 induction of p38 and ERK phosphorylation (79-82). HCV infection also promotes ERK phosphorylation and downstream AP-1 activity (83), whereas blocking ERK signaling reduces intracellular and extracellular HCV RNA copy numbers in human hepatoma cells (84). Our data indicated that ERK phosphorylation was enhanced following p7 expression in Huh7 cells. HCV E2 (85) and core (79) proteins have also been shown to enhance ERK phosphorylation, possibly revealing a conserved immunomodulatory mechanism mediated by several HCV proteins. Furthermore, we observed that MEK inhibition prevented p7-induced SOCS3 expression. These results are consistent with published data showing that inhibition of MEK and ERK with PD98059 prevents SOCS3 induction (86). Taken together, our results indicate that $\mathrm{p} 7 \mathrm{up}$-regulates phosphorylated ERK and that ERK signaling is also required for $\mathrm{p} 7$ 's induction of SOCS3.

Interestingly, Wetherill et al. (87) found that the human papillomavirus oncoprotein E5 (which, like p7, is also believed to be a virally encoded ion channel) induced ERK phosphorylation, which was blocked by the viroporin inhibitors rimantadine and MV006, suggesting that viral ion channel activity is required for this activation of ERK. We similarly saw that the p7 inhibitor, NNDNJ, reduced SOCS3 induction, linking its ion channel activity to the upregulation of SOCS3.

Several studies have demonstrated that HCV infection interferes with TNF- $\alpha$ signaling via its viral proteins, including NS3, NS5B, and core (88-91). Here, we found that expression of $p 7$ inhibited TNF- $\alpha$-mediated ІкB- $\alpha$ degradation and TNF- $\alpha$-mediated NF- $\mathrm{B}$ B promoter activity. We also found that overexpression of $\mathrm{p} 7$ prevented both TRAF2- and TRAF6-mediated NF- $\mathrm{KB}$ activation, suggesting a possible mechanism of TNF- $\alpha$ inhibition. In agreement with this, previous work has shown that SOCS3 interacts with TRAF2 $(19,26)$, and Zhou et al. (24) showed that SOCS3 could degrade TRAF6 by polyubiquitination. Furthermore, SOCS3 can inhibit IL-1 signaling by targeting the TRAF6-transforming growth factor $\beta$-activated kinase 1 (TAK1) complex (25). p7's inhibition of TNF- $\alpha$-mediated NF- $\kappa$ B activity sheds further light on HCV's strategies that modulate TNF- $\alpha$ signaling and may represent another mechanism to suppress proinflammatory signaling. Furthermore, published data show that the viral ion channel from $\mathrm{HIV}$, Viral protein $\mathrm{U}(\mathrm{Vpu})$, also inhibits TNF- $\alpha$-induced IкB- $\alpha$ degradation in both T cells and HeLa cells $(92,93)$. These findings reveal that viral ion channel activity may control proinflammatory signaling pathways and that this may indeed be a novel and conserved immune evasion mechanism.

In summary, our findings suggest a mechanism whereby the HCV-encoded ion channel, p7, induces the negative regulator SOCS3 via STAT3 and ERK activation. Indeed, these discoveries may reveal a molecular mechanism whereby $\mathrm{HCV}$ regulates key inflammatory responses to TNF- $\alpha$, possibly explaining the mild clinical symptoms often experienced during acute $\mathrm{HCV}$ infection. 
A

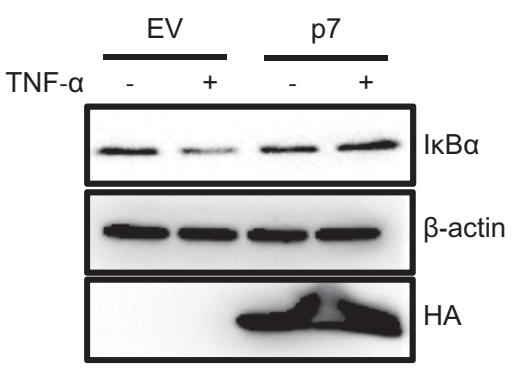

B

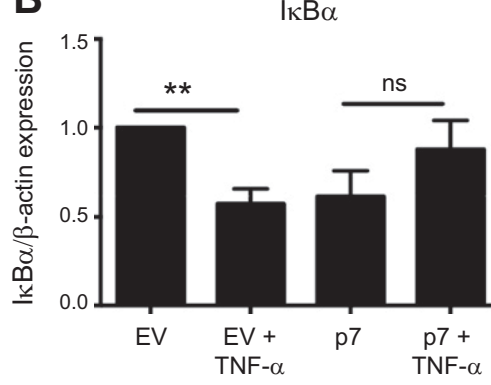

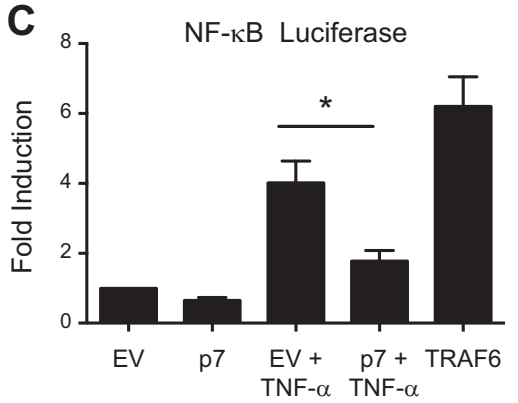

Figure 9. HCV-p7 expression inhibits TNF- $\alpha-$ mediated IкB- $\alpha$ degradation and NF-кB promoter activity. A) Huh7 cells were transfected with $1 \mu \mathrm{g}$ of DNA encoding HCV-p7-HA or EV control for $24 \mathrm{~h}$ prior to stimulation with $20 \mathrm{ng}$ of TNF- $\alpha$ for $20 \mathrm{~min}$, and lysates were probed for IкB- $\alpha, \beta$-actin, and HA. Blots shown are representative of 4 independent experiments. $B$ ) Densitometric analysis of 4 Western blots was performed using Image Lab. Bar graph illustrates the mean \pm sEM increase in IкB- $\alpha$ expression relative to EV control and normalized to $\beta$-actin and analyzed using Student's $t$ test; ns, not significant. $\left.{ }^{* *} P<0.01 . C\right)$ Huh7 cells were transfected with plasmids encoding NF- $\mathrm{kB}-$ regulated firefly luciferase $(1 \mu \mathrm{g})$, constitutively expressed pGL3 Renilla luciferase $(1 \mu \mathrm{g})$, or DNA encoding HCV-p7-HA, EV control, or Flag-TRAF6 $(1 \mu \mathrm{g})$. Transfected cells were left overnight and then treated with $20 \mathrm{ng}$ of TNF- $\alpha$ for $24 \mathrm{~h}$. Cell lysates were assayed for firefly luciferase activity and normalized for transfection efficiency using pGL3 Renilla. Results illustrated are the means \pm SEM of 4 independent experiments in triplicate and analyzed by Student's $t$ test. ${ }^{*} P<0.05$.

\section{ACKNOWLEDGMENTS}

The authors thank Prof. Ralf Bartenschlager (University of Heidelberg, Heidelberg, Germany) for the Jc1 and p7 constructs, Prof. Ron Hay (University of Dundee, Dundee, United Kingdom) for the IкB- $\alpha$ antibody, and Dr. Andrew MacDonald (Leeds University, Leeds, United Kingdom) for the PRDIV6 (activating protein 1)-regulated firefly luciferase construct. This study was funded by the Trinity College Dublin College Award, Health Research Board (POR-20120-57), and Science Foundation Ireland (12/IA/1667). The authors declare no conflicts of interest.

\section{AUTHOR CONTRIBUTIONS}

O. Convery designed and performed the research, analyzed the data, and wrote the manuscript; S. Gargan designed and performed the research, analyzed the data, and wrote the manuscript; M. Kickham performed the research, analyzed the data, and wrote the manuscript; M. Schroder analyzed the data and helped write the description of the results; C. O'Farrelly designed the research, analyzed the data, wrote and edited the manuscript; and N.J. Stevenson designed the research, analyzed the data, wrote and edited the manuscript.

\section{REFERENCES}

1. Toshikuni, N., Arisawa, T., and Tsutsumi, M. (2014) Hepatitis Crelated liver cirrhosis - strategies for the prevention of hepatic decompensation, hepatocarcinogenesis, and mortality. World J. Gastroenterol. 20, 2876-2887

2. Goossens, N., and Hoshida, Y. (2015) Hepatitis C virus-induced hepatocellular carcinoma. Clin. Mol. Hepatol. 21, 105-114

3. Blackard, J. T., Shata, M. T., Shire, N. J., and Sherman, K. E. (2008) Acute hepatitis C virus infection: a chronic problem. Hepatology 47, 321-331

4. Fried, M. W. (2008) Hepatitis C infection with normal liver chemistry tests. Clin. Gastroenterol. Hepatol. 6, 503-505

5. Saito, T., Owen, D. M., Jiang, F., Marcotrigiano, J., and Gale, M., Jr. (2008) Innate immunity induced by composition-dependent RIG-I recognition of hepatitis C virus RNA. Nature 454, 523-527
6. Cao, X., Ding, Q., Lu, J., Tao, W., Huang, B., Zhao, Y., Niu, J., Liu, Y. J., and Zhong, J. (2015) MDA5 plays a critical role in interferon response during hepatitis $\mathrm{C}$ virus infection. J. Hepatol. 62, 771-778

7. Wang, N., Liang, Y., Devaraj, S., Wang, J., Lemon, S. M., and Li, K. (2009) Toll-like receptor 3 mediates establishment of an antiviral state against hepatitis C virus in hepatoma cells. J. Virol. 83, 9824-9834

8. Steen, H. C., and Gamero, A. M. (2013) STAT2 phosphorylation and signaling. JAKSTAT 2, e25790

9. Ivashkiv, L. B., and Donlin, L. T. (2014) Regulation of type I interferon responses. Nat. Rev. Immunol. 14, 36-49

10. Mitchell, T. J., and John, S. (2005) Signal transducer and activator of transcription (STAT) signalling and T-cell lymphomas. Immunology 114, 301-312

11. Schneider, W. M., Chevillotte, M. D., and Rice, C. M. (2014) Interferon-stimulated genes: a complex web of host defenses. Annu. Rev. Immunol. 32, 513-545

12. Carpenter, R. L., and Lo, H. W. (2014) STAT3 target genes relevant to human cancers. Cancers (Basel) 6, 897-925

13. Park, K. H., Lee, T. H., Kim, C. W., and Kim, J. (2013) Enhancement of CCL15 expression and monocyte adhesion to endothelial cells (ECs) after hypoxia/reoxygenation and induction of ICAM-1 expression by CCL15 via the JAK2/STAT3 pathway in ECs. J. Immunol. 190, $6550-6558$

14. Deutsch, M., Papadopoulos, N., Hadziyannis, E. S., and Koskinas, J. (2013) Clinical characteristics, spontaneous clearance and treatment outcome of acute hepatitis $\mathrm{C}$ : a single tertiary center experience. Saudi J. Gastroenterol. 19, 81-85

15. Li, K., Foy, E., Ferreon, J. C., Nakamura, M., Ferreon, A. C., Ikeda, M., Ray, S. C., Gale, M., Jr., and Lemon, S. M. (2005) Immune evasion by hepatitis $\mathrm{C}$ virus NS3/4A protease-mediated cleavage of the Toll-like receptor 3 adaptor protein TRIF. Proc. Natl. Acad. Sci. USA 102, 2992-2997

16. Foy, E., Li, K., Sumpter, R., Jr., Loo, Y. M., Johnson, C. L., Wang, C., Fish, P. M., Yoneyama, M., Fujita, T., Lemon, S. M., and Gale, M., Jr. (2005) Control of antiviral defenses through hepatitis C virus disruption of retinoic acid-inducible gene-I signaling. Proc. Natl. Acad. Sci. USA 102, 2986-2991

17. Li, X. D., Sun, L., Seth, R. B., Pineda, G., and Chen, Z. J. (2005) Hepatitis $C$ virus protease NS3/4A cleaves mitochondrial antiviral signaling protein off the mitochondria to evade innate immunity. Proc. Natl. Acad. Sci. USA 102, 17717-17722

18. Stevenson, N. J., Bourke, N. M., Ryan, E. J., Binder, M., Fanning, L., Johnston, J. A., Hegarty, J. E., Long, A., and O'Farrelly, C. (2013) Hepatitis $\mathrm{C}$ virus targets the interferon- $\alpha$ JAK/STAT pathway by promoting proteasomal degradation in immune cells and hepatocytes. FEBS Lett. 587, 1571-1578

19. Collins, A. S., Ahmed, S., Napoletano, S., Schroeder, M., Johnston, J. A., Hegarty, J. E., O'Farrelly, C., and Stevenson, N. J. (2014) Hepatitis $\mathrm{C}$ virus (HCV)-induced suppressor of cytokine signaling (SOCS) 3 regulates proinflammatory TNF- $\alpha$ responses. J. Leukoc. Biol. 96, 255-263 
20. Duncan, S. A., Baganizi, D. R., Sahu, R., Singh, S. R., and Dennis, V. A. (2017) SOCS proteins as regulators of inflammatory responses induced by bacterial infections: a review. Front. Microbiol. 8, 2431

21. Yoshimura, A., Naka, T., and Kubo, M. (2007) SOCS proteins, cytokine signalling and immune regulation. Nat. Rev. Immunol. 7, 454-465

22. Croker, B. A., Kiu, H., and Nicholson, S. E. (2008) SOCS regulation of the JAK/STAT signalling pathway. Semin. Cell Dev. Biol. 19, 414-422

23. Liu, D., Sheng, C., Gao, S., Yao, C., Li, J., Jiang, W., Chen, H., Wu, J., Pan, C., Chen, S., and Huang, W. (2015) SOCS3 drives proteasomal degradation of TBK1 and negatively regulates antiviral innate immunity. Mol. Cell. Biol. 35, 2400-2413

24. Zhou, X., Liu, Z., Cheng, X., Zheng, Y., Zeng, F., and He, Y. (2015) Socs1 and Socs3 degrades Traf6 via polyubiquitination in LPSinduced acute necrotizing pancreatitis. Cell Death Dis. 6, e2012

25. Frobøse, H., Rønn, S. G., Heding, P. E., Mendoza, H., Cohen, P., Mandrup-Poulsen, T., and Billestrup, N. (2006) Suppressor of cytokine signaling-3 inhibits interleukin-1 signaling by targeting the TRAF-6/TAK1 complex. Mol. Endocrinol. 20, 1587-1596

26. Zhu, X., Bai, J., Liu, P., Wang, X., and Jiang, P. (2016) Suppressor of cytokine signaling 3 plays an important role in porcine circovirus type 2 subclinical infection by downregulating proinflammatory responses. Sci. Rep. 6, 32538

27. Akhtar, L. N., and Benveniste, E. N. (2011) Viral exploitation of host SOCS protein functions. J. Virol. 85, 1912-1921

28. Bode, J. G., Ludwig, S., Ehrhardt, C., Albrecht, U., Erhardt, A., Schaper, F., Heinrich, P. C., and Häussinger, D. (2003) IFN-alpha antagonistic activity of $\mathrm{HCV}$ core protein involves induction of suppressor of cytokine signaling-3. FASEB J. 17, 488-490

29. Hsieh, M. J., Lan, K. P., Liu, H. Y., Zhang, X. Z., Lin, Y. F., Chen, T. Y., and Chiou, H. L. (2012) Hepatitis C virus E2 protein involve in insulin resistance through an impairment of Akt/PKB and GSK3 $\beta$ signaling in hepatocytes. BMC Gastroenterol. 12, 74

30. Huang, Y., Feld, J. J., Sapp, R. K., Nanda, S., Lin, J. H., Blatt, L. M., Fried, M. W., Murthy, K., and Liang, T. J. (2007) Defective hepatic response to interferon and activation of suppressor of cytokine signaling 3 in chronic hepatitis C. Gastroenterology 132, 733-744

31. Walsh, M. J., Jonsson, J. R., Richardson, M. M., Lipka, G. M., Purdie, D. M., Clouston, A. D., and Powell, E. E. (2006) Non-response to antiviral therapy is associated with obesity and increased hepatic expression of suppressor of cytokine signalling 3 (SOCS-3) in patients with chronic hepatitis C, viral genotype 1. Gut 55, 529-535

32. Persico, M., Capasso, M., Persico, E., Svelto, M., Russo, R., Spano, D., Crocè, L., La Mura, V., Moschella, F., Masutti, F., Torella, R., Tiribelli, C., and Iolascon, A. (2007) Suppressor of cytokine signaling 3 (SOCS3) expression and hepatitis $\mathrm{C}$ virus-related chronic hepatitis: insulin resistance and response to antiviral therapy. Hepatology 46, 1009-1015

33. Trengove, M. C., and Ward, A. C. (2013) SOCS proteins in development and disease. Am. J. Clin. Exp. Immunol. 2, 1-29

34. Krebs, D. L., and Hilton, D. J. (2001) SOCS proteins: negative regulators of cytokine signaling. Stem Cells 19, 378-387

35. He, B., You, L., Uematsu, K., Matsangou, M., Xu, Z., He, M., McCormick, F., and Jablons, D. M. (2003) Cloning and characterization of a functional promoter of the human SOCS-3 gene. Biochem. Biophys. Res. Commun. 301, 386-391

36. Croker, B. A., Krebs, D. L., Zhang, J. G., Wormald, S., Willson, T. A., Stanley, E. G., Robb, L., Greenhalgh, C. J., Förster, I., Clausen, B. E., Nicola, N. A., Metcalf, D., Hilton, D.J., Roberts, A. W., and Alexander, W. S. (2003) SOCS3 negatively regulates IL-6 signaling in vivo. Nat. Immunol. 4, 540-545

37. Pirvulescu, M., Manduteanu, I., Gan, A. M., Stan, D., Simion, V., Butoi, E., Calin, M., and Simionescu, M. (2012) A novel pro-inflammatory mechanism of action of resistin in human endothelial cells: upregulation of SOCS3 expression through STAT3 activation. Biochem. Biophys. Res. Commun. 422, 321-326

38. Gatto, L., Berlato, C., Poli, V., Tininini, S., Kinjyo, I., Yoshimura, A., Cassatella, M. A., and Bazzoni, F. (2004) Analysis of SOCS-3 promoter responses to interferon gamma. J. Biol. Chem. 279, 13746-13754

39. Huang, Y. L., Zhao, F., Luo, C. C., Zhang, X., Si, Y., Sun, Z., Zhang, L., Li, Q. Z., and Gao, X. J. (2013) SOCS3-mediated blockade reveals major contribution of JAK2/STAT5 signaling pathway to lactation and proliferation of dairy cow mammary epithelial cells in vitro. Molecules 18, 12987-13002

40. Wada, T., and Penninger, J. M. (2004) Mitogen-activated protein kinases in apoptosis regulation. Oncogene 23, 2838-2849
41. Cargnello, M., and Roux, P. P. (2011) Activation and function of the MAPKs and their substrates, the MAPK-activated protein kinases. Microbiol. Mol. Biol. Rev. 75, 50-83

42. McKay, M. M., and Morrison, D. K. (2007) Integrating signals from RTKs to ERK/MAPK. Oncogene 26, 3113-3121

43. Kawasaki, T., and Kawai, T. (2014) Toll-like receptor signaling pathways. Front. Immunol. 5, 461

44. Kogut, M. H., Genovese, K. J., He, H., and Kaiser, P. (2008) Flagellin and lipopolysaccharide up-regulation of IL-6 and CXCLi2 gene expression in chicken heterophils is mediated by ERK1/2-dependent activation of AP-1 and NF-kappaB signaling pathways. Innate Immun. 14, 213-222

45. Akira, S., and Takeda, K. (2004) Toll-like receptor signalling. Nat. Rev. Immunol. 4, 499-511

46. Karin, M. (1995) The regulation of AP- 1 activity by mitogen-activated protein kinases. J. Biol. Chem. 270, 16483-16486

47. Marshall, C. J. (1996) Ras effectors. Curr. Opin. Cell Biol. 8, 197-204

48. McCubrey, J. A., Steelman, L. S., Chappell, W. H., Abrams, S. L., Wong, E. W., Chang, F., Lehmann, B., Terrian, D. M., Milella, M., Tafuri, A., Stivala, F., Libra, M., Basecke, J., Evangelisti, C., Martelli, A. M., and Franklin, R. A. (2007) Roles of the Raf/MEK/ERK pathway in cell growth, malignant transformation and drug resistance. Biochim. Biophys. Acta 1773, 1263-1284

49. Cruzalegui, F. H., Cano, E., and Treisman, R. (1999) ERK activation induces phosphorylation of Elk-1 at multiple S/T-P motifs to high stoichiometry. Oncogene 18, 7948-7957

50. Ehlting, C., Böhmer, O., Hahnel, M. J., Thomas, M., Zanger, U. M., Gaestel, M., Knoefel, W. T., Schulte Am Esch, J., Häussinger, D., and Bode, J. G. (2015) Oncostatin M regulates SOCS3 mRNA stability via the MEK-ERK1/2-pathway independent of p38(MAPK)/MK2. Cell. Signal. 27, 555-567

51. Wiejak, J., Dunlop, J., Mackay, S. P., and Yarwood, S. J. (2013) Flavanoids induce expression of the suppressor of cytokine signalling 3 (SOCS3) gene and suppress IL-6-activated signal transducer and activator of transcription 3 (STAT3) activation in vascular endothelial cells. Biochem. J. 454, 283-293

52. Dalpke, A. H., Opper, S., Zimmermann, S., and Heeg, K. (2001) Suppressors of cytokine signaling (SOCS)-1 and SOCS-3 are induced by CpG-DNA and modulate cytokine responses in APCs. J. Immunol. 166, 7082-7089

53. Vázquez, N., Greenwell-Wild, T., Rekka, S., Orenstein, J. M., and Wahl, S. M. (2006) Mycobacterium avium-induced SOCS contributes to resistance to IFN-gamma-mediated mycobactericidal activity in human macrophages. J. Leukoc. Biol. 80, 1136-1144

54. Ehlting, C., Lai, W. S., Schaper, F., Brenndörfer, E. D., Matthes, R. J., Heinrich, P. C., Ludwig, S., Blackshear, P. J., Gaestel, M., Häussinger, D., and Bode, J. G. (2007) Regulation of suppressor of cytokine signaling 3 (SOCS3) mRNA stability by TNF-alpha involves activation of the MKK6/p38MAPK/MK2 cascade. J. Immunol. 178, 2813-2826

55. Qin, H., Roberts, K. L., Niyongere, S. A., Cong, Y., Elson, C. O., and Benveniste, E. N. (2007) Molecular mechanism of lipopolysaccharideinduced SOCS-3 gene expression in macrophages and microglia. J. Immunol. 179, 5966-5976

56. Bentham, M. J., Foster, T. L., McCormick, C., and Griffin, S. (2013) Mutations in hepatitis $\mathrm{C}$ virus $\mathrm{p} 7$ reduce both the egress and infectivity of assembled particles via impaired proton channel function. J. Gen. Virol. 94, 2236-2248

57. Qi, H., Chu, V., Wu, N. C., Chen, Z., Truong, S., Brar, G., Su, S. Y., Du, Y., Arumugaswami, V., Olson, C. A., Chen, S. H., Lin, C. Y., Wu, T. T., and Sun, R. (2017) Systematic identification of anti-interferon function on hepatitis $\mathrm{C}$ virus genome reveals $\mathrm{p} 7$ as an immune evasion protein. Proc. Natl. Acad. Sci. USA 114, 2018-2023

58. Steinmann, E., Penin, F., Kallis, S., Patel, A. H., Bartenschlager, R., and Pietschmann, T. (2007) Hepatitis C virus p7 protein is crucial for assembly and release of infectious virions. PLoS Pathog. 3, e103

59. Mankouri, J., Fragkoudis, R., Richards, K. H., Wetherill, L. F., Harris, M., Kohl, A., Elliott, R. M., and Macdonald, A. (2010) Optineurin negatively regulates the induction of IFNbeta in response to RNA virus infection. PLoS Pathog. 6, e1000778

60. Kawaguchi, T., Yoshida, T., Harada, M., Hisamoto, T., Nagao, Y., Ide, T., Taniguchi, E., Kumemura, H., Hanada, S., Maeyama, M., Baba, S., Koga, H., Kumashiro, R., Ueno, T., Ogata, H., Yoshimura, A., and Sata, M. (2004) Hepatitis C virus down-regulates insulin receptor substrates 1 and 2 through up-regulation of suppressor of cytokine signaling 3 . Am. J. Pathol. 165, 1499-1508 
61. Mahony, R., Ahmed, S., Diskin, C., and Stevenson, N. J. (2016) SOCS3 revisited: a broad regulator of disease, now ready for therapeutic use? Cell. Mol. Life Sci. 73, 3323-3336

62. Timofeeva, O. A., Chasovskikh, S., Lonskaya, I., Tarasova, N. I., Khavrutskii, L., Tarasov, S. G., Zhang, X., Korostyshevskiy, V. R., Cheema, A., Zhang, L., Dakshanamurthy, S., Brown, M. L., and Dritschilo, A. (2012) Mechanisms of unphosphorylated STAT3 transcription factor binding to DNA. J. Biol. Chem. 287, 14192-14200

63. Au-Yeung, N., Mandhana, R., and Horvath, C. M. (2013) Transcriptional regulation by STAT1 and STAT2 in the interferon JAK-STAT pathway. JAK-STAT 2, e23931

64. Fink, K. and Grandvaux, N. (2013) STAT2 and IRF9: beyond ISGF3. JAK-STAT 2, e27521

65. Baker, B. J., Qin, H., and Benveniste, E. N. (2008) Molecular basis of oncostatin M-induced SOCS-3 expression in astrocytes. Glia 56, 1250-1262

66. Wortzel, I., and Seger, R. (2011) The ERK cascade: distinct functions within various subcellular organelles. Genes Cancer 2, 195-209

67. Katz, M., Amit, I., and Yarden, Y. (2007) Regulation of MAPKs by growth factors and receptor tyrosine kinases. Biochim. Biophys. Acta 1773, 1161-1176

68. Chen, X. P., Losman, J. A., and Rothman, P. (2000) SOCS proteins, regulators of intracellular signaling. Immunity 13, 287-290

69. Chen, S. L., and Morgan, T. R. (2006) The natural history of hepatitis C virus (HCV) infection. Int. J. Med. Sci. 3, 47-52

70. Rehermann, B. (2009) Hepatitis C virus versus innate and adaptive immune responses: a tale of coevolution and coexistence. J. Clin. Invest. 119, 1745-1754

71. Rébé, C., Végran, F., Berger, H., and Ghiringhelli, F. (2013) STAT3 activation: a key factor in tumor immunoescape. JAK-STAT 2, e23010

72. Auernhammer, C. J., Bousquet, C., and Melmed, S. (1999) Autoregulation of pituitary corticotroph SOCS-3 expression: characterization of the murine SOCS-3 promoter. Proc. Natl. Acad. Sci. USA 96, 6964-6969

73. Yoshida, T., Hanada, T., Tokuhisa, T., Kosai, K., Sata, M., Kohara, M., and Yoshimura, A. (2002) Activation of STAT3 by the hepatitis C virus core protein leads to cellular transformation. J. Exp. Med.196, 641-653

74. Sarcar, B., Ghosh, A. K., Steele, R., Ray, R., and Ray, R. B. (2004) Hepatitis $\mathrm{C}$ virus NS5A mediated STAT3 activation requires cooperation of Jak1 kinase. Virology 322, 51-60

75. Gong, G., Waris, G., Tanveer, R., and Siddiqui, A. (2001) Human hepatitis $\mathrm{C}$ virus NS5A protein alters intracellular calcium levels, induces oxidative stress, and activates STAT-3 and NF-kappa B. Proc. Natl. Acad. Sci. USA 98, 9599-9604

76. Kong, L., Li, S., Yu, X., Fang, X., Xu, A., Huang, M., Wu, X., Guo, Y., Guo, F., and Xu, J. (2016) Hepatitis C virus and its protein NS4B activate the cancer-related STAT3 pathway via the endoplasmic reticulum overload response. Arch. Virol. 161, 2149-2159

77. McCartney, E. M., Helbig, K. J., Narayana, S. K., Eyre, N. S., Aloia, A. L., and Beard, M. R. (2013) Signal transducer and activator of transcription 3 is a proviral host factor for hepatitis $\mathrm{C}$ virus. Hepatology 58, 1558-1568

78. Canfield, S., Lee, Y., Schröder, A., and Rothman, P. (2005) Cutting edge: IL-4 induces suppressor of cytokine signaling-3 expression in B cells by a mechanism dependent on activation of p38 MAPK. J. Immunol. 174, 2494-2498

79. Giambartolomei, S., Covone, F., Levrero, M., and Balsano, C. (2001) Sustained activation of the Raf/MEK/Erk pathway in response to EGF in stable cell lines expressing the Hepatitis C Virus (HCV) core protein. Oncogene 20, 2606-2610
80. Hayashi, J., Aoki, H., Kajino, K., Moriyama, M., Arakawa, Y., and Hino, O. (2000) Hepatitis C virus core protein activates the MAPK/ERK cascade synergistically with tumor promoter TPA, but not with epidermal growth factor or transforming growth factor alpha. Hepatology 32, 958-961

81. Mazzocca, A., Sciammetta, S. C., Carloni, V., Cosmi, L., Annunziato, F., Harada, T., Abrignani, S., and Pinzani, M. (2005) Binding of hepatitis $\mathrm{C}$ virus envelope protein $\mathrm{E} 2$ to $\mathrm{CD} 81$ up-regulates matrix metalloproteinase-2 in human hepatic stellate cells. J. Biol. Chem. $\mathbf{2 8 0}$, 11329-11339

82. Zhao, L. J., Wang, W., Ren, H., and Qi, Z. T. (2013) ERK signaling is triggered by hepatitis C virus E2 protein through DC-SIGN. Cell Stress Chaperones 18, 495-501

83. Tran, S. C., Pham, T. M., Nguyen, L. N., Park, E. M., Lim, Y. S., and Hwang, S. B. (2016) Nonstructural 3 protein of hepatitis C virus modulates the tribbles homolog $3 /$ Akt signaling pathway for persistent viral infection. J. Virol. 90, 7231-7247

84. Pei, R., Chen, H., Lu, L., Zhu, W., Beckebaum, S., Cicinnati, V., Lu, M., and Chen, X. (2011) Hepatitis $\mathrm{C}$ virus infection induces the expression of amphiregulin, a factor related to the activation of cellular survival pathways and required for efficient viral assembly. J. Gen. Virol. 92, 2237-2248

85. Zhao, L. J., Zhang, X. L., Zhao, P., Cao, J., Cao, M. M., Zhu, S. Y., Liu, H. Q., and Qi, Z. T. (2006) Up-regulation of ERK and p38 MAPK signaling pathways by hepatitis C virus E2 envelope protein in human T lymphoma cell line. J. Leukoc. Biol. 80, 424-432

86. Isobe, A., Takeda, T., Sakata, M., Yamamoto, T., Minekawa, R., Hayashi, M., Auernhammer, C. J., Tasaka, K., and Murata, Y. (2006) STAT3-mediated constitutive expression of SOCS3 in an undifferentiated rat trophoblast-like cell line. Placenta 27, 912-918

87. Wetherill, L. F., Holmes, K. K., Verow, M., Müller, M., Howell, G., Harris, M., Fishwick, C., Stonehouse, N., Foster, R., Blair, G. E., Griffin, S., and Macdonald, A. (2012) High-risk human papillomavirus E5 oncoprotein displays channel-forming activity sensitive to smallmolecule inhibitors. J. Virol. 86, 5341-5351

88. Chen, Y., He, L., Peng, Y., Shi, X., Chen, J., Zhong, J., Chen, X., Cheng, G., and Deng, H. (2015) The hepatitis C virus protein NS3 suppresses TNF- $\alpha$-stimulated activation of NF-кB by targeting LUBAC. Sci. Signal. 8, ral18

89. Choi, S. H., Park, K. J., Ahn, B. Y., Jung, G., Lai, M. M., and Hwang, S. B. (2006) Hepatitis C virus nonstructural $5 \mathrm{~B}$ protein regulates tumor necrosis factor alpha signaling through effects on cellular IkappaB kinase. Mol. Cell. Biol. 26, 3048-3059

90. Marusawa, H., Hijikata, M., Chiba, T., and Shimotohno, K. (1999) Hepatitis C virus core protein inhibits Fas- and tumor necrosis factor alpha-mediated apoptosis via NF-kappaB activation. J. Virol. 73, 4713-4720

91. Joo, M., Hahn, Y. S., Kwon, M., Sadikot, R. T., Blackwell, T. S., and Christman, J. W. (2005) Hepatitis C virus core protein suppresses NFkappaB activation and cyclooxygenase- 2 expression by direct interaction with IkappaB kinase beta. J. Virol. 79, 7648-7657

92. Bour, S., Perrin, C., Akari, H., and Strebel, K. (2001) The human immunodeficiency virus type $1 \mathrm{Vpu}$ protein inhibits NF-kappa B activation by interfering with beta TrCP-mediated degradation of Ikappa B. J. Biol. Chem. 276, 15920-15928

93. Strebel, K. (2014) HIV-1 Vpu - an ion channel in search of a job. Biochim. Biophys. Acta 1838, 1074-1081

Received for publication April 2, 2018. Accepted for publication March 28, 2019. 